\title{
13. UPPER EOCENE TEKTITES OF THE NEW JERSEY CONTINENTAL MARGIN, SITE 904
}

\author{
Cecilia M.G. McHugh, ${ }^{2,3}$ Scott W. Snyder, ${ }^{4}$ Jean-Francois Deconinck, ${ }^{5}$ Yoshiki Saito, ${ }^{6}$ \\ Miriam E. Katz, ${ }^{3}$ and Marie-Pierre Aubry ${ }^{7}$
}

\begin{abstract}
Tektite-bearing sediment was recovered from the New Jersey continental slope (1123 m water depth) by the Ocean Drilling Program (ODP) at Site 904. The biostratigraphy, mineralogy, and geochemistry of Site 904 tektites and enclosing sediment permit us to interpret their source and the sequence of events that led to their deposition.

The tektites of Site 904 occur within upper Eocene (Zones P15, NP19/20) biosiliceous chalks. The tektites are concentrated in three well-defined laminae that occur in a 5-cm-thick section (Interval 150-904A-45X-2, 84.5-89.5 cm). Tektites are abundant between the laminae and occur sporadically, above and below the layers, through a $24-\mathrm{cm}$-thick section (Interval 150904A-45X-2, 79-103 cm). Small-sized tektites $(<63 \mu \mathrm{m})$ occur rarely above the $24-\mathrm{cm}$-thick interval for another $19 \mathrm{~cm}$ (Interval $150-904 \mathrm{~A}-45 \mathrm{X}-2,60-79 \mathrm{~cm}$ ). Grain-size distribution indicates that the tektites and associated detrital minerals fine upward. The coarse-grained fractions occur in the bottom and middle laminae and the fine-grained fractions are concentrated in the upper lamina. Because benthic foraminifer assemblages are bathyal, turbidity currents originating in shallow water could not have deposited the tektites and detrital minerals. The abundance of planktonic versus benthic foraminifers also argues against displacement of sediment from shallow water.

Site 904 tektites, as at Deep Sea Drilling Project (DSDP) Site 612, are associated with shock metamorphosed minerals and are considered to be an impact ejecta. Gravity settling of the ejecta through the air and the water column is the proposed depositional process. The structures and deformation features contained in the sediment that yielded the tektites indicate that deposition of the ejecta on the New Jersey continental slope was influenced by mass-wasting and gravity-flow processes. These processes are interpreted to have occurred as a result of disturbances to the seafloor and water column by tsunami and possibly shock-generated waves. Biostratigraphic and major oxide analyses correlate the upper Eocene tektites of Site 904 to those of Site 612, to the Exmore breccia at Exmore, Virginia, and to the North American strewn field. The range in the major oxide composition suggest that the tektites originated from a single but heterogeneous source.
\end{abstract}

\section{INTRODUCTION}

The high pressures and temperatures generated by impacts of extraterrestrial bodies melt terrestrial material and form glass (King, 1977; Glass, 1984; Koeberl, 1986; Glass et al., 1986). Tektites are a rare type of impact glass grouped by its size into tektites $(>1000 \mu \mathrm{m})$ and microtektites $(<1000 \mu \mathrm{m})$. Tektites are homogeneous glasses that are rich in silica and generally do not contain primary crystallites and relic grains (Glass, 1982). Rarely, some tektites have been found to contain metallic spherules and shocked mineral grains (Glass, 1990). Tektites can have splash, ablated, or blocky forms (Glass and Koeberl, 1989; Glass, 1990). Microtektites are also silica rich and are primarily splash forms (spheres, disks, dumbbells, and teardrops). Microkrystites, another type of impact-produced glass closely associated with upper Eocene tektites and microtektites, are glassy spherules that contain primary crystallites (Glass and Burns, 1987; Glass, 1990). The only known samples of microkrystites, contain clinopyroxene as a primary crystallite. Tektites, microtektites, and microkrystites can be correlated by their chemistry, age, and petrologi-

'Mountain, G.S., Miller, K.G., Blum, P., Poag, C.W., and Twichell, D.C. (Eds.), 1996. Proc. ODP, Sci. Results, 150: College Station, TX (Ocean Drilling Program).

${ }^{2}$ Department of Geology, Queens College, City University of New York, 65-30 Kissena Blvd., Flushing, NY 11367, U.S.A. cmmqc@qcvaxa.acc.qc.edu

${ }^{3}$ Lamont-Doherty Earth Observatory, Columbia University, Palisades, NY 10964. U.S.A.

${ }^{4}$ Department of Geology, East Carolina University, Greenville, NC 27858-4353, U.S.A.

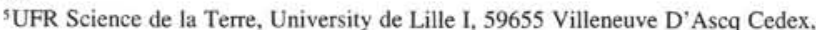
France.

${ }^{6}$ Marine Geology Department, Geological Survey of Japan, Higashi 1-1-3, Tsukuba, Ibaraki 305, Japan.

${ }^{7}$ Laboratoire de Geologie du Quaternaire, CNRS-Luminy, Marseille Cedex 9, France.

${ }^{7}$ Woods Hole Oceanographic Institution, Woods Hole, MA 02543, U.S.A. cal and physical characteristics over large areas of the Earth known as "strewn fields" (Koeberl, 1986; Glass, 1990). Tektite strewn fields can in some instances be correlated to an impact crater (Faul, 1966; Glass et al., 1979; Koeberl, 1994).

Tektites belonging to the North American strewn field were deposited during the late Eocene in Texas, Georgia, and also have been recovered from deep-sea deposits from the Caribbean Sea, the Gulf of Mexico, and Barbados (Barnes, 1973; King, 1962; Glass and Zwart, 1979; Glass et al., 1985; Fig. 1). Recently, an upper Eocene tektite layer was discovered on the New Jersey continental margin at Deep Sea Drilling Project (DSDP) Site 612 (Thein, 1987). Site 612 was drilled on the New Jersey middle slope (1404 m water depth) and the tektite interval was recovered from biosiliceous nannofossil chalks.

Controversy surrounds the number of late Eocene impacts. Two impacts (Glass et al., 1985; Glass and Burns, 1987), three impacts (Keller et al., 1987; D'Hondt et al., 1987), three or perhaps four impacts (Miller et al., 1991), and more than six impacts (Hazel, 1989) could have occurred within a short period of time (10 to 20 k.y.). Site 612 tektites have been correlated to the North American strewn field (Koeberl and Glass, 1988; Poag et al., 1992, 1993, 1994b) and to a possibly slightly older event(s) (Glass, 1989; Miller et al., 1991; Wei, 1993). In another view, Site 612 tektites have been correlated to an event of the same age but from a different source than the North American strewn field (Poag and Aubry, 1995).

Site 612 tektite layer is thick and contains an abundant coarsegrained component; therefore, it is generally agreed that the source crater must be nearby (Thein, 1987; Glass, 1989; Koeberl, 1989; Stecher et al., 1989). Poag et al. (1994b) discovered in Chesapeake Bay a structure that was formed in upper Eocene to Lower Cretaceous sediments and extends into the pre-Mesozoic crystalline basement. The buried structure is $85 \mathrm{~km}$ wide and 1.5 to $2.0 \mathrm{~km}$ deep. Because of the size, location, age, and composition of the sedimentary 


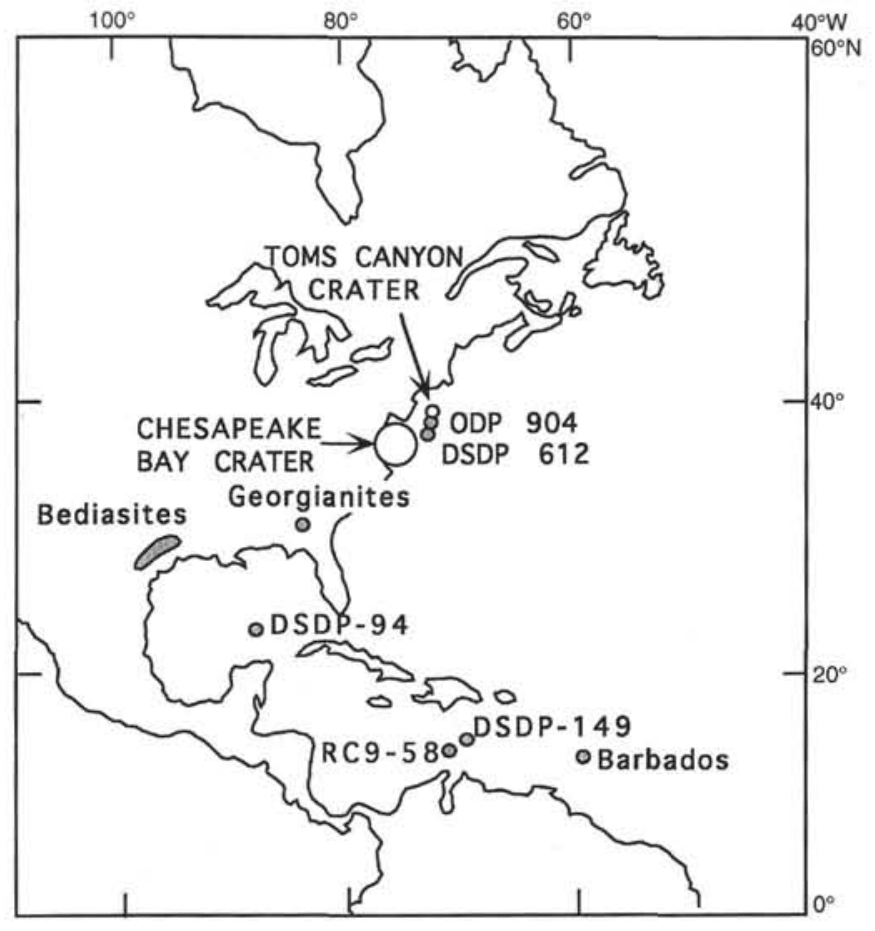

Figure 1. Location of Sites 904 and 612 on the New Jersey continental margin, and other locations from which tektites of the North American strewn field have been found. Chesapeake Bay and Toms Canyon "impact craters" are possible sources of late Eocene tektites from Sites 904 and 612 and the North American strewn field. The Chesapeake Bay "impact crater" is located $\sim 300 \mathrm{~km}$ away from the New Jersey continental slope.

and crystalline rocks from which it occurs, Poag et al. (1994b) suggested that the Chesapeake Bay structure is an impact crater and the source of the North American strewn field. Poag et al. (1992) and Poag and Aubry (1995) proposed that another, smaller structure (the "Toms Crater"), located on the outer continental shelf $40 \mathrm{~km}$ northnorthwest of DSDP Site 612 is an impactcrater and the source for the Site 612 tektites. The structure is 15 to $25 \mathrm{~km}$ wide, 200 to $500 \mathrm{~m}$ deep, and occurs in Paleocene to upper Eocene carbonates and Cretaceous siliciclastics.

Site 904 was drilled on the New Jersey middle slope (1123 m water depth) and recovered upper Eocene sediment that contains a tektite-bearing horizon (Fig. 2). Site 904 is $4.9 \mathrm{~km}$ (2.6 nmi) upslope of Site 612. Upper Eocene sediment was recovered from Site 903, drilled on the upper continental slope. However, no tektites have been identified from Site 903 from apparently coeval sediments, at this point. The biostratigraphy, mineralogy, and major oxide composition of the Site 904 tektites and enclosing sediment were studied to interpret their source and the sequence of events that led to their deposition.

\section{METHODS OF SAMPLE ANALYSIS}

Ten samples from the tektite-bearing interval of Section 150$904 \mathrm{~A}-45 \mathrm{X}-2$ at $74-96 \mathrm{~cm}$ and one at $102-103 \mathrm{~cm}$ were analyzed (Table 1). The 1-g samples were disaggregated in distilled water, wetsieved through a $63-\mu \mathrm{m}$ mesh, and dry-sieved through 125-, 250-, $500-, 1000-$, and $1500-\mu \mathrm{m}$ meshes. The $<63-\mu \mathrm{m}$ size fraction was used for clay mineralogy and calcareous nannofossils studies. Some of the 63- to $125-\mu \mathrm{m}$-size fractions were prepared as petrographic slides and described. The $>250-\mu \mathrm{m}$ size fractions were described and counted using a binocular microscope with up to $50 \times$ magnification. Tektites (tektite fragments and microtektites), quartz, and glauconite grains were counted.

Benthic and planktonic foraminifers were studied from all sampled intervals. Washed residue from bulk samples weighing one gram each were examined for planktonic foraminifers. All specimens larger that $150 \mu \mathrm{m}$ were picked and, where preservation permitted, identified to species or subspecies level. A total of 31 indigenous species belonging to 14 genera were identified. In addition, six reworked species belonging to five genera occur sporadically through the samples (Fig. 3).

Scanning electron microscope and energy dispersive X-ray analyses (SEM/EDX) were conducted at Lamont-Doherty Earth Observatory on carbon-coated tektites from all sampled intervals. Representative tektite samples from the three major tektite-bearing layers $(150-904 \mathrm{~A}-45 \mathrm{X}-2,85-86 \mathrm{~cm}, 87-88 \mathrm{~cm}$, and $88-89 \mathrm{~cm})$ and four other tektite-bearing intervals $(150-904 \mathrm{~A}-45 \mathrm{X}-2,86-87 \mathrm{~cm}, 91-92$ $\mathrm{cm}, 92-93 \mathrm{~cm}$, and $102-103 \mathrm{~cm}$ ) were prepared for major oxide analyses and for petrographic studies by mounting them in epoxy on glass slides and grinding them. Electron microprobe analyses were performed on the Cameca Camebax/Micro wavelength dispersive system at Lamont-Doherty Earth Observatory. An accelerating voltage of $15 \mathrm{kV}$ and sample currents of $10 \mathrm{nA}$ for $\mathrm{K}$ and $\mathrm{Na}$ and $25 \mathrm{nA}$ for $\mathrm{Si}, \mathrm{Ti}, \mathrm{Al}, \mathrm{Fe}, \mathrm{Mg}, \mathrm{Mn}, \mathrm{Ca}, \mathrm{P}$, and $\mathrm{Cr}$ were used. To minimize alkali loss from glasses a 5- $\mu \mathrm{m}$ raster was used. Glasses were calibrated on glass standards (Juan de Fuca).

Clay mineral associations from 14 samples within Interval 150$904 \mathrm{~A}-45 \mathrm{X}-2,52-121 \mathrm{~cm}$, were studied using X-ray diffraction, differential thermal analyses, and chemical analyses. Clays were deflocculated by successive washing with distilled water, after decarbonation of the crushed rock with $0.2 \mathrm{~N} \mathrm{HCl}$. The clay fraction (particles less than $2 \mu \mathrm{m}$ ) was separated by sedimentation and centrifugation (Brown and Brindley, 1980; Holtzapffel, 1985). X-ray diffraction patterns were obtained using a Phillips PW 1730 diffractometer with $\mathrm{CuK} \alpha$ radiation and Ni filter. A tube voltage of $40 \mathrm{kV}$ and a tube current of $25 \mathrm{~mA}$ were utilized. For each sample, three different X-ray diffraction patterns were obtained, after air-drying, ethylene-glycol solvation, and heating at $490^{\circ} \mathrm{C}$ for $2 \mathrm{hr}$. The goniometer scanned from $2.5^{\circ}$ to $28.5^{\circ} 2 \theta$ for air-dried and glycol-solvated samples, and from $2.5^{\circ}$ to $14.5^{\circ} 2 \theta$ for heated samples. Clay minerals were identified according to the position of the (001) series of basal reflections on the three X-ray diffraction patterns (Brown and Brindley, 1980; Moore and Reynolds, 1989). Semiquantitative estimates were based on the peak intensity and on the area of the main diffraction peak of each clay mineral (Holtzapffel, 1985). Differential thermal analyses were conducted under Ar gas using a thermo-analyzer TAG 24 SETARAM at a heating rate of $10^{\circ} \mathrm{C}$ per minute up to $1200^{\circ} \mathrm{C}$. Chemical analyses of the clay fraction of three samples were performed using a Camebax microprobe. One sample (150-904A-45X-2, 88-89 cm) was from a tektite layer, and the two others from the biosiliceous chalks located below and above.

Calculations for the passage of the shock waves were derived from the compressional velocity of seismic waves through soft limestones $(1700-4200 \mathrm{~m} / \mathrm{s}$ ) for a distance of $300 \mathrm{~km}$ (Dobrin and Savit, 1988). Calculations for the settling velocities of the grains were estimated for $5 \mathrm{~km}$ of air and $1 \mathrm{~km}$ of seawater (Table 2). Numbers used in water were for a fluid density of $1025 \mathrm{~kg} / \mathrm{m}^{3}$ at $20^{\circ} \mathrm{C}, 3.5 \%$ salinity, $1 \mathrm{~atm}$ pressure, and a viscosity of $0.00109 \mathrm{~Pa}$. Numbers used in air were for a fluid density of $1.3 \mathrm{~kg} / \mathrm{m}^{3}$ at $20^{\circ} \mathrm{C}$, and a viscosity of $0.000015 \mathrm{~Pa}$. The densities used were for quartz at $2650 \mathrm{~kg} / \mathrm{m}^{3}$ and for pyroxene at $3200 \mathrm{~kg} / \mathrm{m}^{3}$ that have similar densities as the tektites and the microkrystites. The calculations were made for grains of 32 , $63,150,250,500,1000,2000,4000,8000$, and $15,000 \mu \mathrm{m}$. Settling velocities were calculated based on Gibbs et al. (1971). The velocity of the tsunami waves was calculated as the square root of gravity 


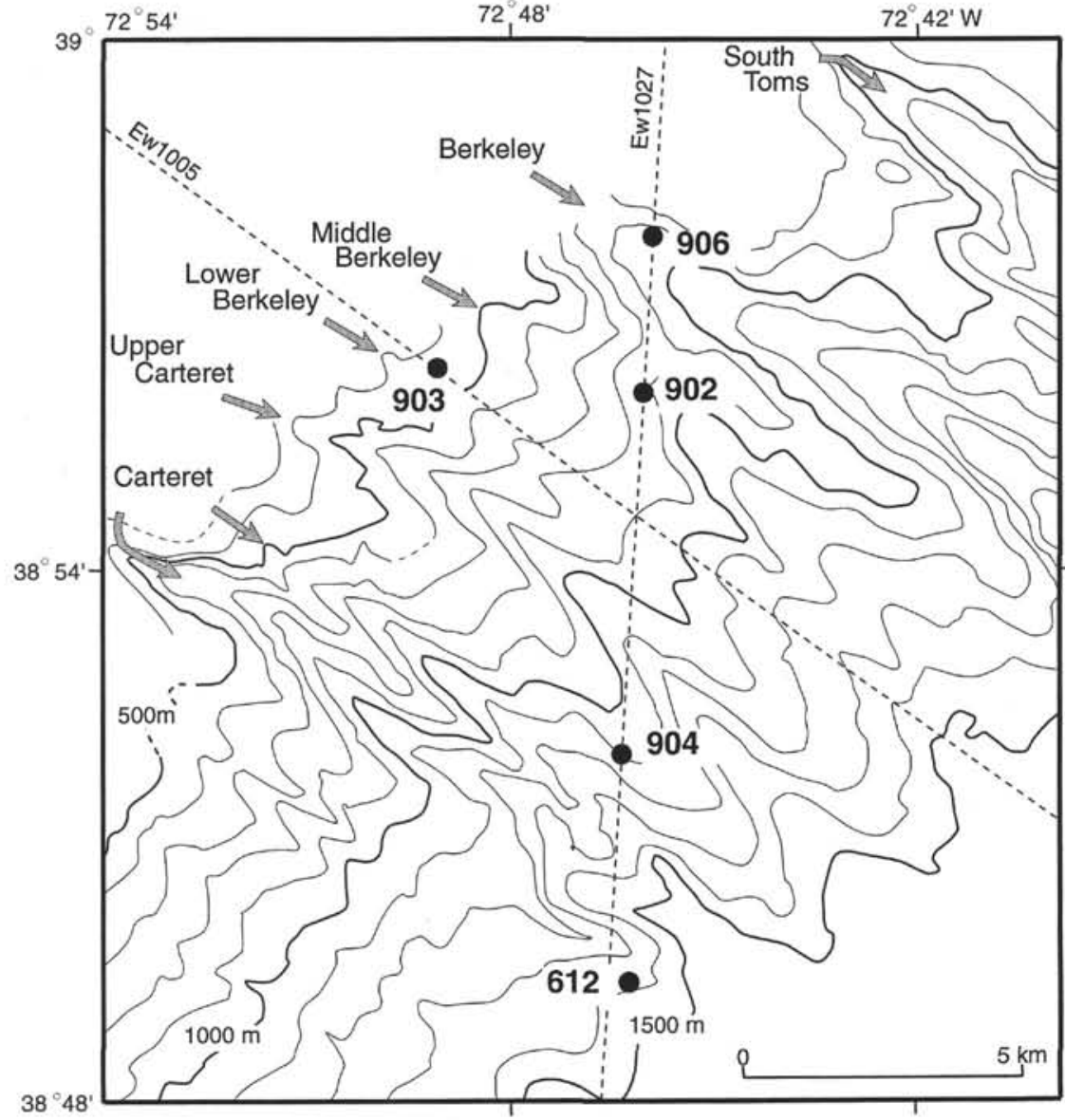

Figure 2. Detailed SeaBeam bathymetric map of the study area. During Leg 150 four sites were drilled in canyon and intercanyon regions of the New Jersey upper and middle slope (500-1500 m water depth): Sites $902-$ 904 and Site 906. Upper Eocene tektite-bearing sediment was recovered from Site 904 , which is only $5 \mathrm{~km}$ upslope from DSDP Site 612, where sediment containing tektites also was recovered. At this point, tektites have not been found from correlative upper Eocene sediment at Site 903.
Table 1. Number of tektites counted by size from the sampled intervals.

\begin{tabular}{|c|c|c|c|c|}
\hline \multicolumn{5}{|c|}{ Sample } \\
\hline \multicolumn{2}{|c|}{$150-904 \mathrm{~A}-45 \mathrm{X}-2$} & \multicolumn{3}{|c|}{ Number/Size } \\
\hline $\begin{array}{l}\text { Depth } \\
\text { (mbsf) }\end{array}$ & $\begin{array}{c}\text { Interval } \\
(\mathrm{cm})\end{array}$ & $1000-1500 \mu \mathrm{m}$ & $500-1000 \mu \mathrm{m}$ & $250-500 \mu \mathrm{m}$ \\
\hline 415.64 & $74-75$ & 0 & 0 & 0 \\
\hline 451.69 & $79-80$ & 0 & 0 & 29 \\
\hline 415.72 & $82-83$ & 0 & 0 & 3 \\
\hline 415.75 & $85-86$ & 3 & 97 & 1851 \\
\hline 415.76 & $86-87$ & $i$ & 64 & 840 \\
\hline 415.77 & $87-88$ & 52 & 498 & 3071 \\
\hline 415.78 & $88-89$ & 38 & 423 & 2841 \\
\hline 415.81 & $91-92$ & 2 & 13 & 114 \\
\hline 415.82 & $92-93$ & 0 & 2 & 11 \\
\hline 415.85 & $95-96$ & 0 & 1 & 4 \\
\hline 415.92 & $102-103$ & \multicolumn{2}{|c|}{6 (not counted by size) } & \\
\hline
\end{tabular}

$\left(9.81 \mathrm{~m} / \mathrm{s}^{2}\right)$ times the water depth at the "impact site" $(200 \mathrm{~m})$. The time it took the first tsunami wave to arrive to Site 904 equaled the traveled distance $(300 \mathrm{~km})$ divided by the velocity $(6.708 \mathrm{~s})$, which equals $1.86 \mathrm{hr}$.

\section{DESCRIPTION OF TEKTITE-BEARING SEDIMENT}

The tektite glasses are concentrated in three distinct laminae that occur in a 5-cm-thick interval from 84.5 to $89.5 \mathrm{~cm}$ at Section 150 $904 \mathrm{~A}-45 \mathrm{X}-2$ (Fig. 4). Tektites are abundant in between the laminae and occur rarely at Interval 150-904A-45X-2, 91-103 cm, and at Interval $150-904 \mathrm{~A}-45 \mathrm{X}-2,79-83 \mathrm{~cm}$ (see Table 1). Smaller-sized tektites $<63 \mu \mathrm{m}$ occur sporadically at Interval 150-904A-45X-2, 60-79 $\mathrm{cm}$ (Shipboard Scientific Party, 1994). The tektite grain-size distributions among the three laminae indicate an overall fining-upward trend (Fig. 5). In the lowermost lamina (1 cm thick), tektite size distribution is as follows: $86 \%$ (of the total number counted) are in the 250 - to $500-\mu \mathrm{m}$ size fraction, $13 \%$ in the 500 - to $1000-\mu \mathrm{m}$ size fraction, and $1 \%$ in the 1000 - to $1500-\mu \mathrm{m}$ size fraction. The base of the bottom lamina forms an abrupt contact with the underlying clay. The top contact is not as clearly defined and tektites occur within the 1- to $1.5-\mathrm{cm}$-thick clay layer that separates the bottom and middle laminae.

In the middle lamina $(0.5-1 \mathrm{~cm}$ thick), $85 \%$ (of the total number of tektites counted) are in the 250 - to $500-\mu \mathrm{m}$ size fraction, $14 \%$ in the 500 - to $1000-\mu \mathrm{m}$ size fraction, and $1 \%$ in the 1000 - to $1500-\mu \mathrm{m}$ size fraction. The grain-size distributions in the bottom and middle laminae are similar, the main difference being that the middle layer contains more tektites (3621) per gram of sediment than the bottom layer (3302 tektites; see Table 1).

A fining-upward trend is observed from the middle to the top laminae. In the uppermost lamina $(0.5-0.75 \mathrm{~cm}$ thick) $90 \%$ of the counted tektites are in the 250 - to $500-\mu \mathrm{m}$ size fraction, $9 \%$ are in the 500 to $1000-\mu \mathrm{m}$ size fraction, and $0.2 \%$ are in the $1000-$ to $1500-\mu \mathrm{m}$ size fraction. Laminated silty clay occurs between the middle and top laminae. The structures within the silty clay are noticeable because of dark and light color variations, possibly the result of pyrite and/or glauconite concentrations.

Tektites also occur in the laminated interval between the middle and top laminae at Site 904 , but their number per gram of sediment is 


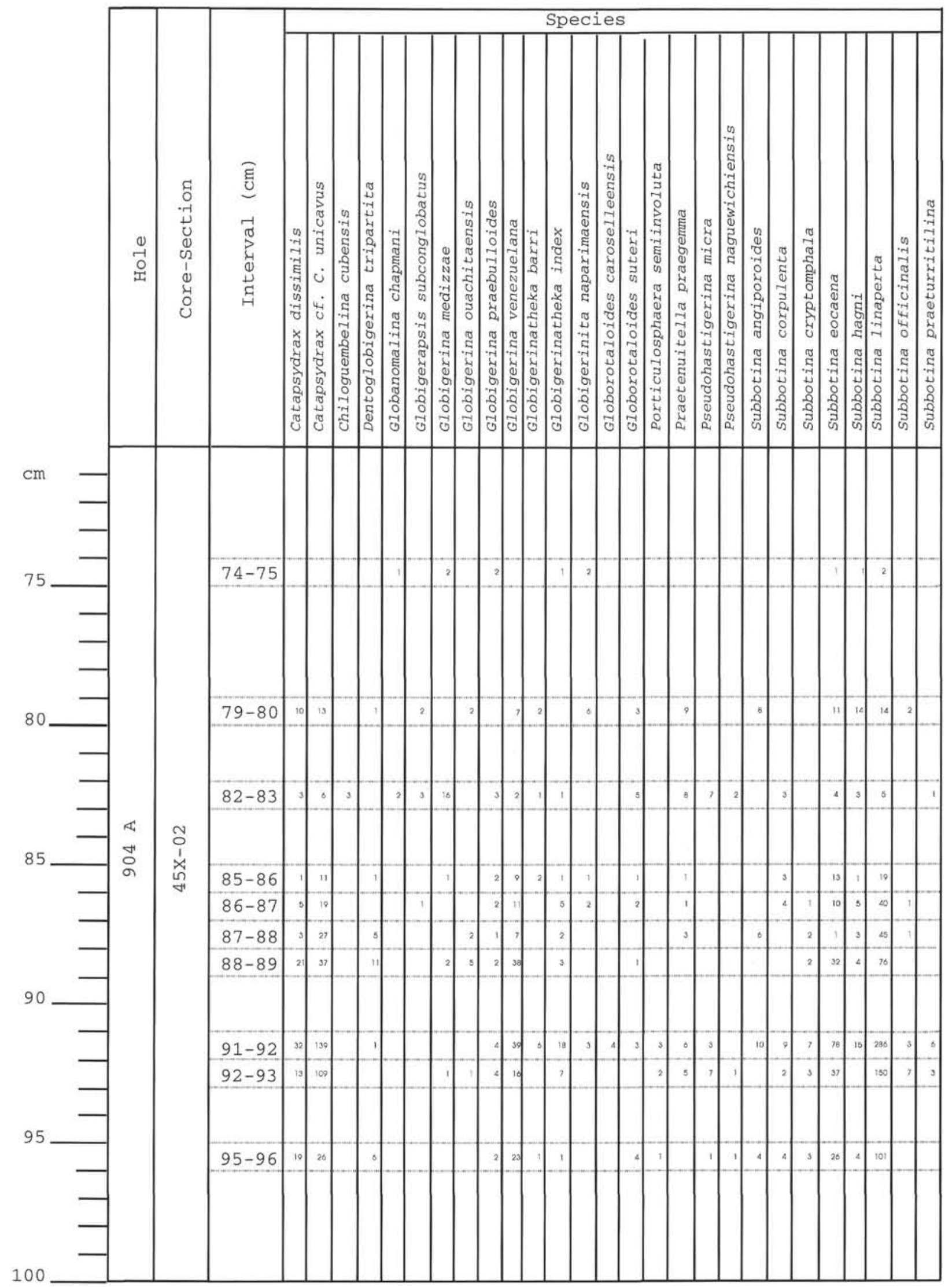

Figure 3. Planktonic foraminifer biostratigraphy of the tektite-bearing horizon. 


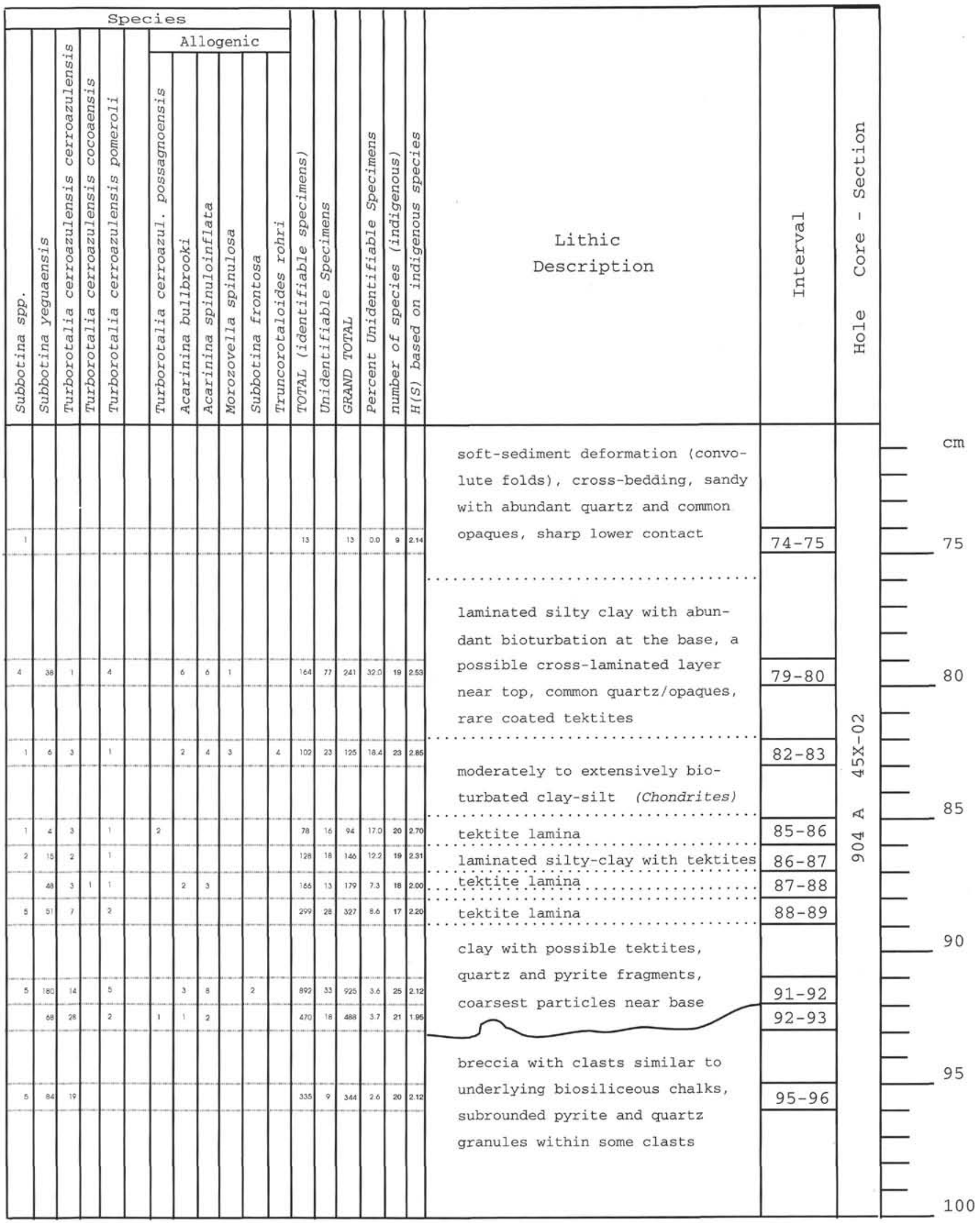

Figure 3 (continued). 
Table 2. Settling time (in days) for quartz and pyroxene grains calculated by particle size.

\begin{tabular}{rccrrrr}
\hline $\begin{array}{c}\text { Diameter } \\
(\mu \mathrm{m})\end{array}$ & $\begin{array}{c}\text { Quartz } \\
(1 \mathrm{~km} \text { air })\end{array}$ & $\begin{array}{c}\text { Pyroxene } \\
(1 \mathrm{~km} \text { air })\end{array}$ & $\begin{array}{c}\text { Quartz } \\
(5 \mathrm{~km} \mathrm{sea})\end{array}$ & $\begin{array}{c}\text { Pyroxene } \\
(5 \mathrm{~km} \text { sea })\end{array}$ & $\begin{array}{c}\text { Quartz } \\
(\text { total days })\end{array}$ & $\begin{array}{c}\text { Pyroxene } \\
(\text { total days })\end{array}$ \\
\hline 32 & 0.7793 & 0.6568 & 14.1209 & 10.6029 & 14.9002 & 11.2597 \\
63 & 0.2444 & 0.2107 & 3.7956 & 2.8848 & 4.0400 & 3.0954 \\
150 & 0.0717 & 0.0636 & 0.8127 & 0.6428 & 0.8845 & 0.7063 \\
250 & 0.0392 & 0.0351 & 0.3759 & 0.3061 & 0.4151 & 0.3412 \\
500 & 0.0191 & 0.0172 & 0.1575 & 0.1321 & 0.1766 & 0.1493 \\
1,000 & 0.0102 & 0.0092 & 0.0776 & 0.0662 & 0.0878 & 0.0754 \\
2,000 & 0.0059 & 0.0053 & 0.0432 & 0.0371 & 0.0490 & 0.0424 \\
4,000 & 0.0036 & 0.0033 & 0.0263 & 0.0227 & 0.0299 & 0.0260 \\
8,000 & 0.0024 & 0.0022 & 0.0171 & 0.0147 & 0.0194 & 0.0169 \\
15,000 & 0.0017 & 0.0015 & 0.0119 & 0.0103 & 0.0136 & 0.0118 \\
\hline
\end{tabular}

less in the laminated interval than in the top layer (905 and 1951, respectively; see Table 1). The tektite grain-size distribution in the interval between the middle and top laminae is consistent with a finingupward trend because $92 \%$ of the tektites are in the $250-$ to $500-\mu \mathrm{m}$ size fraction, $8 \%$ are in the 500 - to $1000-\mu \mathrm{m}$ size fraction, and $0.1 \%$ are in the 1000 - to $1500-\mu \mathrm{m}$ size fraction. Moderate to heavy bioturbation occurred in a 3-cm-thick section above and possibly within a 0.5 -cm-layer beneath the top lamina.

There are similarities between the tektite-bearing sediment of Sites 904 and 612. At both sites, sand-sized tektites are concentrated in a 5- to 6-cm zone near the bottom of the tektite-yielding sediment and are found scattered in an approximately $24-\mathrm{cm}$-thick interval. A difference between the two sites is that small-sized $(<63 \mu \mathrm{m})$ tektites occur rarely at Site 904 for $19 \mathrm{~cm}$ above the 24-cm-thick interval, from 451.69 to 415.5 mbsf (Shipboard Scientific Party, 1994).

A breccia deposit occurs beneath the tektite layer at Site 904 from 415.98 to 415.81 mbsf (Fig. 6). This is not the case at Site 612 where the tektite layer was deposited on an erosional surface (Glass, 1989; Poag and Aubry, 1995). The breccia clasts of Site 904 are apparent because their lighter color contrasts with a slightly darker matrix. Tektite fragments (up to $1500 \mu \mathrm{m}$ ), quartz (up to $5 \mathrm{~mm}$ in diameter), an elliptical lithic clast ( $19 \mathrm{~mm}$ in diameter), and subrounded pyrite (up to $7 \mathrm{~mm}$ in diameter) occur in the breccia deposit at $415.92 \mathrm{mbsf}$. The quartz grain shows evidence of shock metamorphism (multiple sets of lamellae), has a sugary texture, and breaks easily, when touched, and is shattered. The lithic clast has a rim of iron oxide and contains quartz grains $(200-500 \mu \mathrm{m}$ in size) that also show evidence of shock metamorphism. The base of the mass-wasting deposit is marked by an 8-cm-thick zone of fluid pathways, and its top by an angular dipping contact. Above this contact there is a 2- to 3-cm-thick layer of clay that contains abundant quartz, pyrite, and tektite fragments. The coarsest grains (up to $4 \mathrm{~mm}$ in diameter) occur along the surface of the inclined contact. This clay interval is interpreted as a slurry generated by the mass-wasting event.

The sedimentary section above the tektite laminae (from 415.74 to $415.63 \mathrm{mbsf})$ has two depositional styles. The lower interval $(6 \mathrm{~cm}$ thick) is composed of laminated silty clay abundantly bioturbated. An interval $(0.5 \mathrm{~cm}$ thick) that appears cross-laminated occurs near the top of the sequence and is recognized by dark to light color variations and an increase in the abundance of opaque minerals from $2 \%$ to $8 \%$ (Shipboard Scientific Party, 1994). Unusual features within this interval include copper and tin coatings on the surface of a tektite and zinc and iron occurring on a matrix fragment. More analyses need to be conducted from this interval to determine if the occurrence of these elements is common or rare.

The upper interval is $5 \mathrm{~cm}$ thick, has a sharp contact at its base, and exhibits soft sediment deformation features such as convolute folds and flame structures. Upward within this interval is an increase in the occurrence of opaque minerals from $3 \%$ to $10 \%$. Horizontally compacted clasts of two different colors are present at the top of the sequence. These clasts may also be interpreted as burrows. The contact with the overlaying biosiliceous chalk is wavy.
Soft sediment deformation which may be related to the deposition of the tektites occurs below the tektite horizon from 416.4 to 418.9 mbsf (Shipboard Scientific Party, 1994). The deformed strata are recognized by color variations in the biosiliceous chalks.

A layer interpreted to be correlative to the tektite-bearing sediment at Sites 904 and 612 was encountered in Hole 903C from 1109.4 to $1109.3 \mathrm{mbsf}$ (Section 150-903C-56R-6). The layer is within the upper Eocene clayey biosiliceous chalks. The sequence is $6 \mathrm{~cm}$ thick and composed of brownish gray silt and very fine sand with parallel laminations 1- to 2-mm in thickness (Fig. 7). No tektites have been found in this layer yet.

\section{TEKTITE MINERALOGY}

The tektites at Site 904 range in size from less than $63 \mu \mathrm{m}$ up to $1500 \mu \mathrm{m}$. Generally tektite fragments are concentrated in the lower layers, while microtektites are common toward the middle and top of the interval. Tektite fragments are irregularly shaped and vary from transparent yellow to brown (Pl. 1). Some tektite fragments are cemented together by pyrite. At Site 904 there are transparent white to yellow microtektites with splash forms that exhibit dumbbell, teardrop, spherical, oval, and elongated shapes. Some of these microtektites are larger than $1 \mathrm{~mm}$ (Pl. 2). Frosted-pumice-like, opaque white to yellow tektites are common. The surfaces of the tektites are commonly coated by bronze-colored pyrite crystals, bright yellow sulfur crystals, and white crystals of calcite and gypsum. Coatings of pyrite are also common on all grain surfaces.

A wide range of surface textures is observed on the tektites (Pl. 3). Some have smooth glassy surfaces while others are etched, corroded, striated, or covered with circular pits. Vesicular textures and conchoidal fractures are most common (Pl. 4).

At Site 904, a large part of the ejecta debris consists of quartz and feldspar (Fig. 8). Quartz occurs from 415.93 to $415.65 \mathrm{mbsf}$ and its grain-size distribution fines upward. The largest grains, up to $2 \mathrm{~cm}$ in diameter, occur in the breccia deposit at 415.93 mbsf. A few quartz grains ( 0.05 to $1 \mathrm{~mm}$ in diameter) occur scattered in the clay above the mass-wasting deposit and in the bottom laminae. Quartz, as at Site 612 (Glass, 1989), is concentrated in the middle and top tektitebearing laminae (Fig. 9). In the middle layer at $415.77 \mathrm{mbsf}$ of the quartz grains between 250 and $1000 \mu \mathrm{m}, 13 \%$ are in the 500 - to 1000 $\mu \mathrm{m}$ size fraction and $87 \%$ are in the $250-$ to $500-\mu \mathrm{m}$ size fraction. Abundances of quartz grains between 250 and $1000 \mu \mathrm{m}$ in the top layer at $415.75 \mathrm{mbsf}$ are: in the 500 - to $1000-\mu \mathrm{m}$ fraction $2 \%$, and in the 250 - to $500-\mu \mathrm{m}$ fraction, $98 \%$. Some quartz and feldspar show evidence of shock (Pl. 5).

Multiple sets of lamellae are noted on some quartz and feldspar grains. These features are identical to shock lamellae developed in quartz grains of impactites (Robertson et al., 1968). Evidence of shock metamorphism in quartz and feldspar grains was also documented at Site 612 (Thein, 1987; Bohor et al., 1988). Therefore, it is interpreted that some of the quartz and feldspar grains have under- 

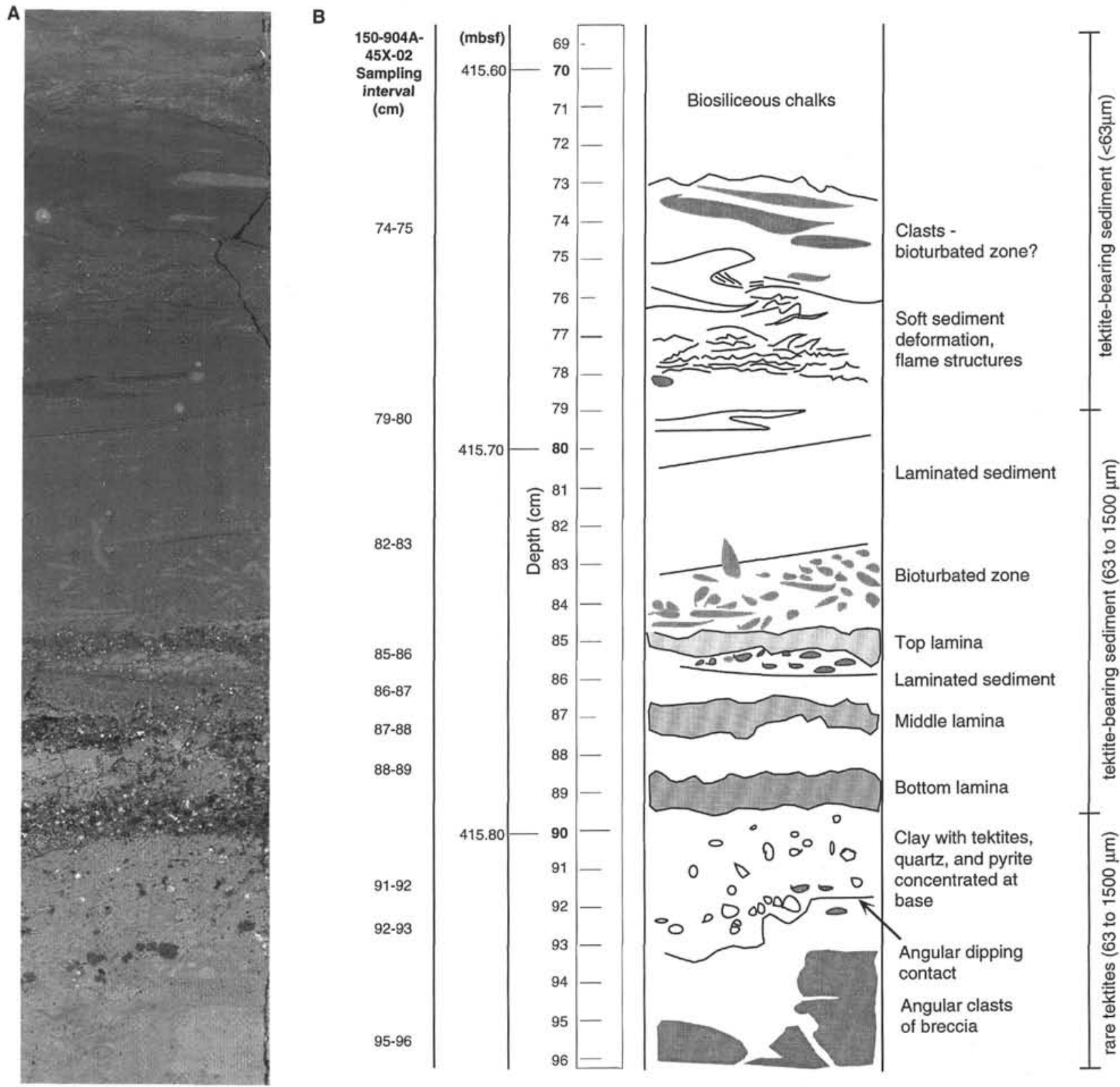

Figure 4. Tektite-bearing Interval 150-904A-45X-2, 70-96 cm. A. Close-up photograph of the biosiliceous chalks showing three well-defined laminae, from 84.5 to $89.5 \mathrm{~cm}$, that contain abundant tektites. A laminated interval occurs between the middle and top laminae. Only fine-grained $(<250 \mu \mathrm{m})$ tektites occur from 84.5 to $79 \mathrm{~cm}$. Interval $150-904 \mathrm{~A}-45 \mathrm{X}-2,78-84.5 \mathrm{~cm}$, above the upper tektite lamina, contains laminated sediment. Soft-sediment deformation features occur toward the top of the section, Interval 150-904A-45X-2, 73-78 cm. A breccia deposit occurs beneath the tektite laminae in Interval 150-904A-45X-2, $89.5-96 \mathrm{~cm}$. B. Interpretation of the tektite interval showing (from the bottom up) breccia deposit, clay containing scattered grains, including tektites and quartz concentrated at the bottom, tektite laminae, laminated sediment above the tektite laminae, and soft-sediment deformation features toward the top of the interval.

gone shock deformation. Glauconite also occurs in the tektite-bearing layer and, as with quartz is abundant in the top and middle layers, and fines upward (Fig. 10). This suggests that glauconite is also part of the ejecta, but it has been questioned whether glauconite grains would survive the impact (Glass, 1989). Although glauconite grains are abundant in the top and middle layers they also occur above and below these intervals, and are commonly associated with the Eocene biosiliceous chalks.

The tektite, quartz, and glauconite abundances were calculated for grains ranging in size from 250 to $1500 \mu \mathrm{m}$ (Fig. 11). Quartz is most abundant in the top lamina at 415.75 mbsf where it makes up $52 \%$ of the counted grains. Tektite and glauconite concentrations within this interval are $43 \%$ and $5 \%$, respectively. The second largest occurrence of quartz is within the middle tektite-yielding lamina at $415.77 \mathrm{mbsf}$ where it constitutes $33 \%$ of the grains, $62 \%$ are tektites, and glauconite contributes $5 \%$ to the total grain count. Quartz is least abundant in the lower lamina at 415.78 mbsf where it makes up only $11 \%$ of the grains. Tektites are the major component (86\%) and glauconite is minor at $2 \%$. Quartz and glauconite also occur at $415.81,415.76$, 415.72 , and $415.69 \mathrm{mbsf}$ where they coincide with laminated intervals and with the top of the breccia deposit.

\section{CLAY MINERALOGY}

The clay mineral associations are composed dominantly of smectite, with minor illite and kaolinite (Table 3). The studied interval has fluctuations in the percentages of clay minerals (Fig. 12). The clay 
150-904A

$45 X-2$

Sampling

interval Depth

(cm) (mbsf)

79-80

$\mid$

415.7

$82-83$

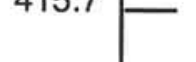

86-87

$87-88$

88-89

\begin{tabular}{l|l|}
$88-89$ & \multicolumn{1}{|}{4} \\
$91-92$ & \\
$92-93$ & \\
\hline $95-96$ &
\end{tabular}

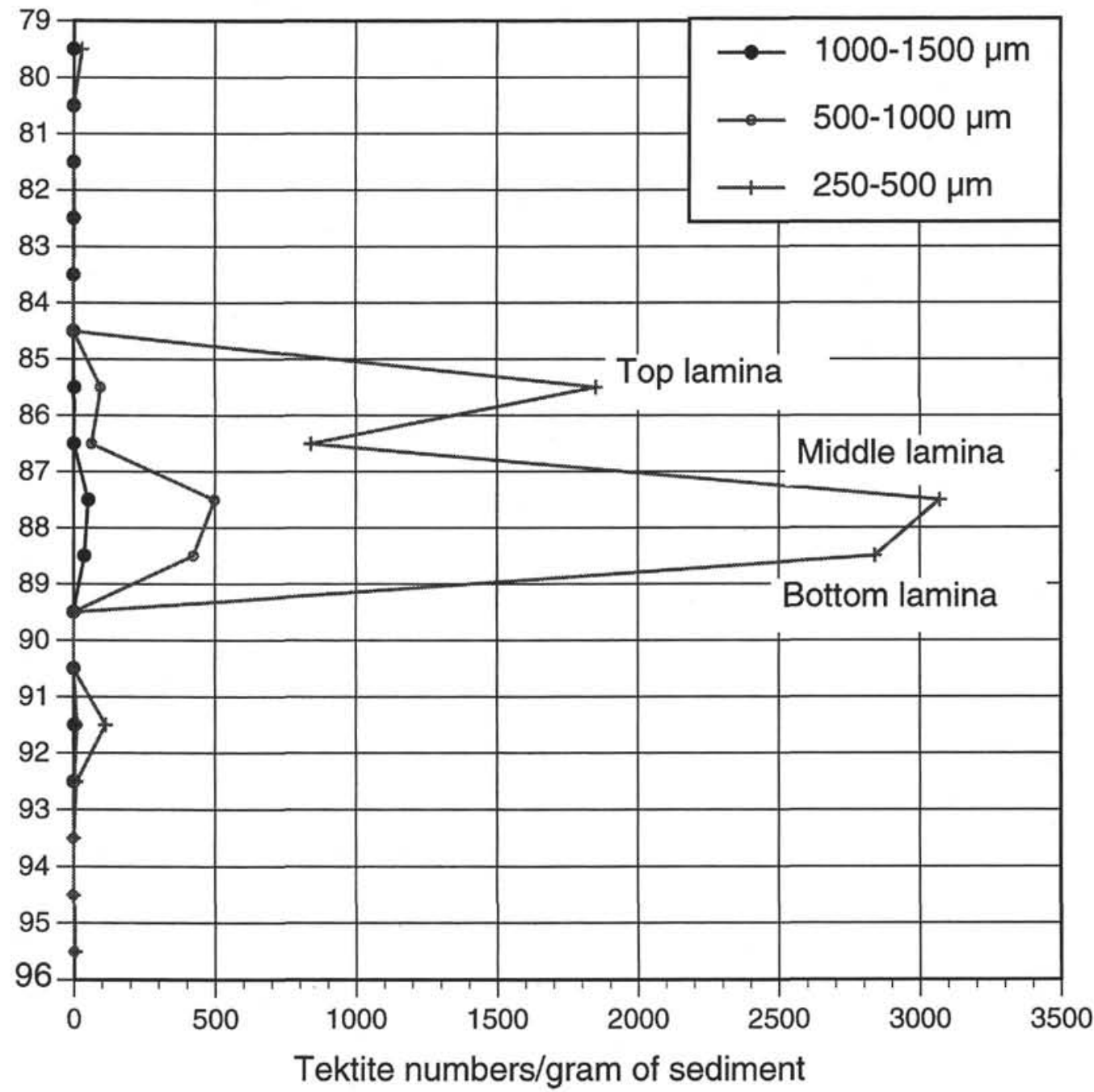

Figure 5. Grain-size distribution of tektites showing fining-upward trend, Interval 150-904A-45X-2, 79-96 cm. Tektites were also found at Interval 150-904A$45 \mathrm{X}-2,102-103 \mathrm{~cm}$ (see Table 1). The grain-size distribution of the bottom and middle laminae is very similar, the only difference being that the middle laminae contains more tektites. The top lamina is dominantly fine-grained.

fraction of the tektite layer is enriched with smectite, with only traces of illite and kaolinite. Smectites are more abundant above than below the tektite laminae (Shipboard Scientific Party, 1994).

Above and below the tektite layer, the chemical composition of the clay fraction of the biosiliceous chalks is almost the same in Samples 150-904A-45X-2, 52-53 cm, and 150-904A-45X-2, 109-110 $\mathrm{cm}$ (Table 4). Impurities of quartz are probably responsible for the relatively high silica content. By contrast, the chemical composition of the clay fraction from the tektite layer is different. The clay fraction from Sample 150-904A-45X-2, 88-89 cm, contains more magnesium and sodium and less iron, potassium, and calcium. The clay fraction of this sample is characterized by a differential thermal curve displaying two successive endotherms at $490^{\circ}$ and $680^{\circ} \mathrm{C}$, corresponding to dehydroxylation. This suggests a mixture of two distinct types of smectites (Deconinck and Chamley, in press).

\section{MAJOR OXIDE CHEMISTRY}

Major oxide analyses were conducted on 46 tektite fragments and microtektites, ranging in size from 500 to $1500 \mu \mathrm{m}$. These samples were obtained from the three laminae and seven other intervals including three below the bottom lamina (415.93-415.78 mbsf). Major oxides for the Site 904 tektites have a narrow range in composition (Table 5). Except for two points the $\mathrm{SiO}_{2}$ content ranges from 70.5 to $79.1 \mathrm{wt} \%$. At Site 904, major oxides $\mathrm{Al}_{2} \mathrm{O}_{3}, \mathrm{FeO}, \mathrm{MgO}, \mathrm{CaO}$, and $\mathrm{Na}_{2} \mathrm{O}$ when plotted against $\mathrm{SiO}_{2} \mathrm{wt} \%$ form a mixing trend that shows an inverse relationship with $\mathrm{SiO}_{2}$ content (Fig. 13). The major oxide $\mathrm{K}_{2} \mathrm{O}$ when plotted against $\mathrm{SiO}_{2}$ wt $\%$ shows no relationship with silica and a broad scatter of points. The major oxide $\mathrm{TiO} 2$ does not vary with $\mathrm{SiO}_{2}$ content. Only one tektite specimen has a much different range in composition than the rest. This sample (150-904A-45X-2, 


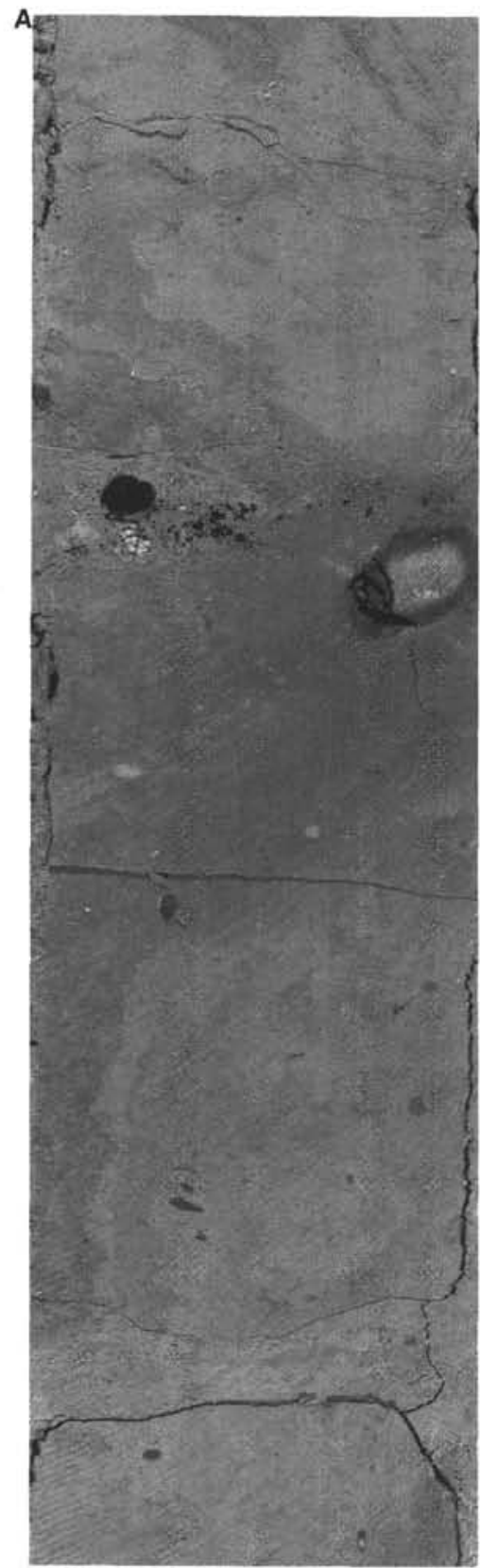

B $150-904 A$

$45 X-2$

Sampling interval

(cm)

$102-103$

Figure 6. A. Close-up photograph of breccia deposit with angular clasts, and large lithic, quartz, and tektite fragments contained in the breccia. Fluid escape features occur in Interval 150-904A-45X-2, 107-113 cm. B. Interpretation of breccia deposit showing clasts and fluid features. Interval 150-904-45X-2, 94-116 $\mathrm{cm}$.

$88-89 \mathrm{~cm}$, \#5) contains $69 \mathrm{wt} \% \mathrm{SiO}_{2}$, very low $\mathrm{Al}_{2} \mathrm{O}_{3}(1 \mathrm{wt} \%)$ and $\mathrm{FeO}(0.11 \mathrm{wt} \%)$, low $\mathrm{K}_{2} \mathrm{O}$ (1 wt \%), high $\mathrm{CaO}(6 \mathrm{wt} \%)$ and $\mathrm{MgO}(4$ wt\%), and very high $\mathrm{Na}_{2} \mathrm{O}(12 \mathrm{wt} \%)$. Another tektite (Sample 150$904 \mathrm{~A}-45 \mathrm{X}-2,102-103 \mathrm{~cm}, \# 3$ ) has low $66.59 \mathrm{SiO}_{2}$ wt $\%$ but similar values for the rest of the oxides as the other analyzed samples.

The major oxide composition and mixing trend of the Site 904 tektites is very similar to that of the tektite fragments at Site 612. Glass (1989) analyzed tektite fragments of Site 612 and obtained silica values that range between 69.9 and $77.5 \mathrm{SiO}_{2}$ wt\% (Fig. 13). The tektites at Site 904 tend to have higher $\mathrm{SiO}_{2}$ wt $\%$ values than the microtektites at Site 612. Except for one point Glass (1989) obtained a range between 66.4 to $75.7 \mathrm{wt} \%$ for the Site 612 microtektites. At present, microkrystites have not been found at Site 904. Microkrystites were found concentrated at the bottom of the tektite-bearing interval at Site 612 (Glass, 1989). A possibility is that at Site $612 \mathrm{mi}-$ crokrystites occur in the $250 \mu \mathrm{m}$ or less size fractions that have not been analyzed yet at Site 904 . Microkrystites at Site 612 are characterized by lower $\mathrm{SiO}_{2}$ (average $61.5 \mathrm{wt} \%$ ), $\mathrm{Al}_{2} \mathrm{O}_{3}$, and $\mathrm{TiO}_{2}$, and higher $\mathrm{FeO}, \mathrm{MgO}$, and $\mathrm{CaO}$ content than the tektites at Site 904 and than the microtektites and tektite fragments at Site 612 (Glass, 1989). It is predicted that when the smaller size fractions $(250 \mu \mathrm{m}$ or less $)$ are analyzed at Site 904, microkrystites, tektite fragments, and microtektites with lower $\mathrm{SiO}_{2}$ wt\% values and a wider range in major oxide composition similar to those of Site 612 will be obtained.

Low total values of major oxides were obtained for several of the samples. These lower values may reflect the presence of sulfur because pyrite occurs on many of the tektites. These samples should also have higher iron content. One such sample is $150-904 \mathrm{~A}-45 \mathrm{X}-2$, $87-88 \mathrm{~cm}$ (\#6), because it contains higher iron, and low major oxide totals. However, the low major oxide totals of the analyzed samples 


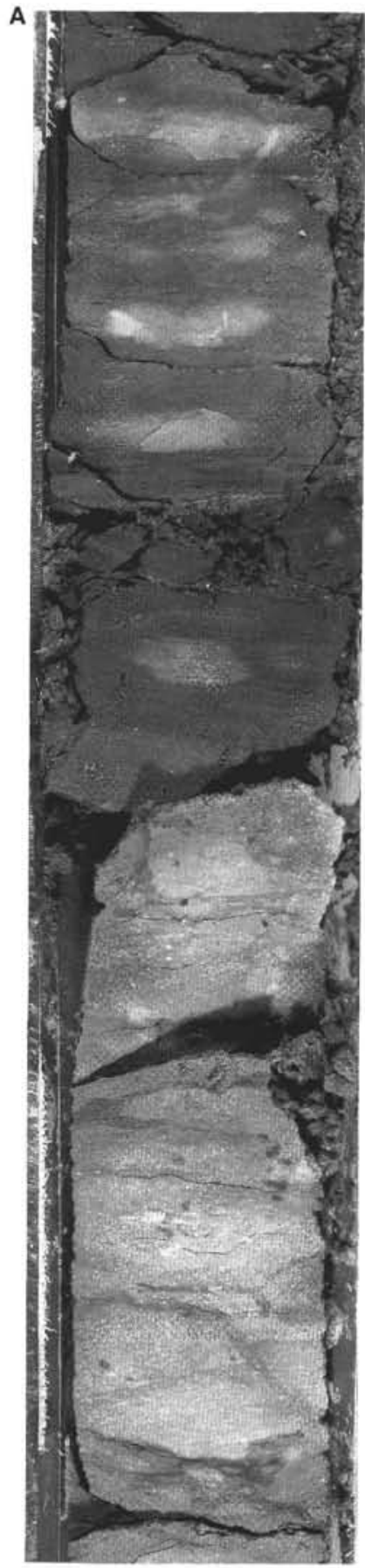

B

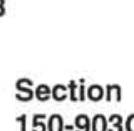
150-903C-56R-6

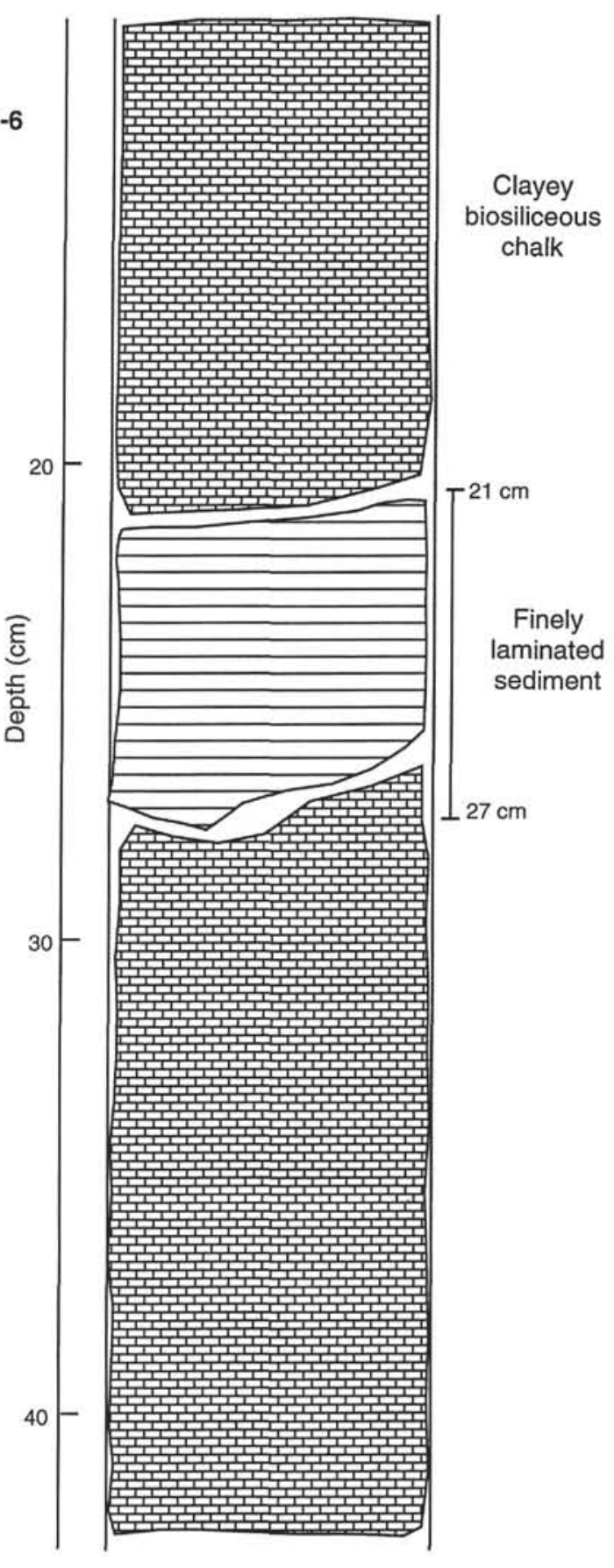

Figure 7. A. Upper Eocene, Interval 150-903C-56R-6, 12-42 cm, of brownish-gray, clayey biosiliceous chalks correlative to the tektite-bearing sediment of Site 904. Interval $150-903 \mathrm{C}-56 \mathrm{R}-6,21-27 \mathrm{~cm}$, is similar in appearance to Interval $150-904 \mathrm{~A}-45 \mathrm{X}-2,73-85 \mathrm{~cm}$, above the tektite laminae. At this point, tektites have not been recovered from Hole 903C. B. Interpretation of upper Eocene, Interval 150-903C-56R-6, 12-42 cm, showing laminated clayey biosiliceous chalks in Interval $150-903 \mathrm{C}-56 \mathrm{R}-6,21-27 \mathrm{~cm}$.

from the bottom interval (150-904A-45X-2, 102-103 cm) and a few other intervals cannot be explained by the presence of pyrite. Another possible explanation of the low total values is that the samples are hydrated.

Major oxide composition of tektites from Site 904 is within the range of the North American strewn field (Table 6). A difference is that the $\mathrm{Na}_{2} \mathrm{O}$ wt\% values are lower and the $\mathrm{K}_{2} \mathrm{O}$ wt\% values are higher. A similar chemistry is observed with the tektites of Site 612. Koeberl and Glass (1988) plotted on a diagram sodium vs. potassium values for the tektites of the North American strewn field. Bediasites from Texas, georgiaites from Georgia, and the Cuban, Barbados, and
Site 612 tektites show a mixing trend. The low sodium and high potassium values of Site 904 tektites are also consistent with the mixing trend of the North American strewn field because they would plot on the same region as the Site 612 tektites.

\section{BIOSTRATIGRAPHY}

At Site 904 the tektite-bearing layer is assigned by calcareous nannofossils to lower upper Eocene Zone NP19-20 (Shipboard Scientific Party, 1994). Middle Eocene, Zone NP16, occurs $8 \mathrm{~m}$ below 

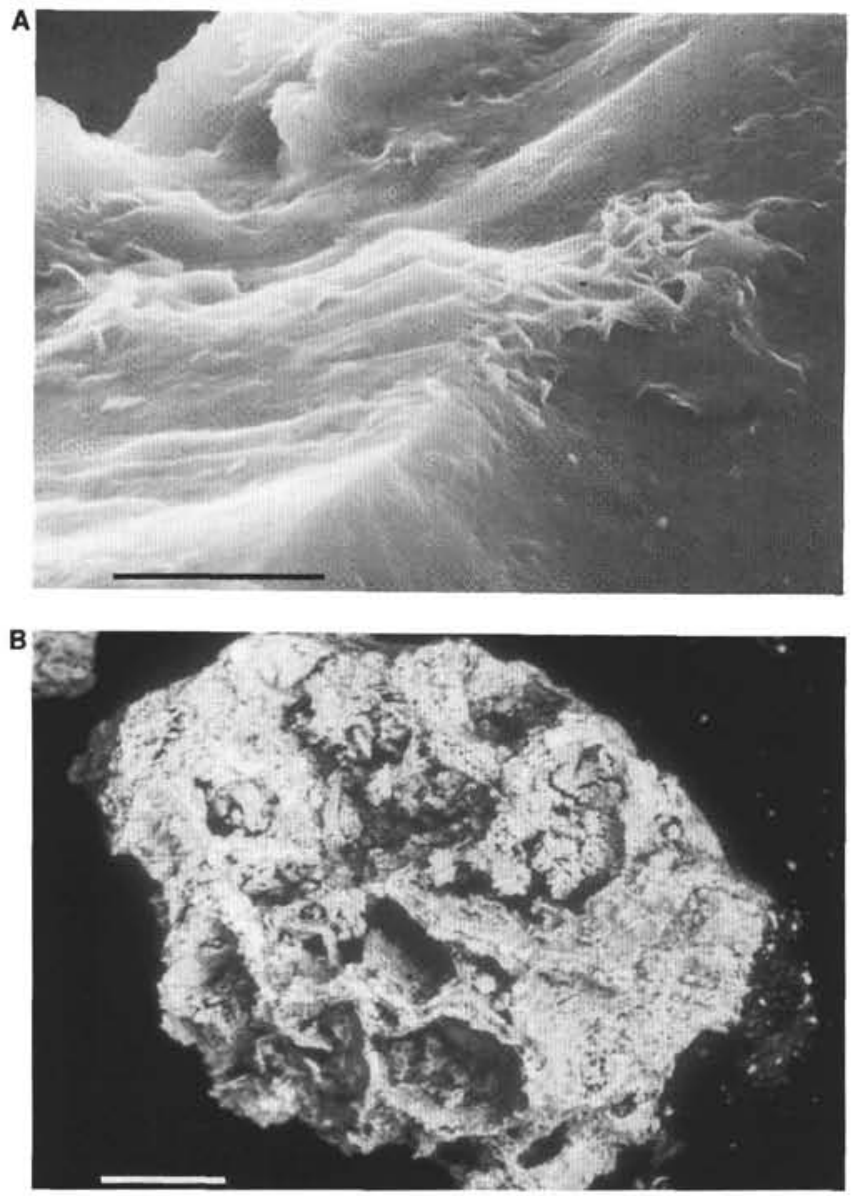

Figure 8. As at Site 612, quartz is part of the Site 904 ejecta. A. Possible deformation features on surface of quartz grain, Sample 150-904A-45X-2, 79-80. Scale bar $=4 \mu \mathrm{m}$. B. Quartzite grain, Sample 150-904A-45X-2, 86$87 \mathrm{~cm}$. Scale bar $=100 \mu \mathrm{m}$.

the tektite interval at 423.43 mbsf. Upper Eocene, Zone NP18, lies unconformably over the middle Eocene (Fig. 14). At Hole 903C, the sediment correlative to the Site 904 and 612 tektite-bearing horizon, was assigned to upper Eocene Zone NP19-20 (1109.4-1109.3 mbsf). The NP18/NP19-20 zonal boundary occurs approximately $3 \mathrm{~m}$ (1112.4 mbsf) below this horizon. The middle Eocene in Hole 903C is approximately $6 \mathrm{~m}(1115.0 \mathrm{mbsf})$ below the horizon correlative to the tektite-bearing sediment of Sites 904 and 612 .

Biostratigraphic studies of planktonic foraminifers of Site 612 sediment indicate a major unconformity ( $\sim 4$ m.y.) immediately beneath the tektite layer (Poag, Watts, et al., 1987; Miller et al., 1991; Poag and Aubry, 1995). Sediment that contains tektites at Site 612 is assigned to lower upper Eocene Zone P15 of Berggren and Miller (1988), and sediment below the unconformity to middle Eocene Zones P12-lower P14.

The tektite-bearing interval at Site 904 is assigned to planktonic foraminifer Zone P15, as defined by Berggren and Miller (1988). Berggren and Miller established the base of this zone at the first occurrence of Porticulasphaera semiinvoluta. P. cf. P. semiinvoluta was reported from sediments immediately above the tektite horizon at nearby Site 612 (Miller et al., 1991). Poag and Aubry (1995) identified $P$. semiinvoluta from both Site 612 and the correlative Exmore breccia at Exmore, Virginia. The presence of $P$. semiinvoluta in samples immediately below the tektite laminae at Site 904 indicates that the laminae must postdate the base of Zone P15 (Fig. 3). In addition, ancillary species which first occur in Zone P15 (Globigerina ouchi- taensis, G. praebulloides, Subbotina angiporoides, Pseudohastigerina naguewichiensis, Praetenuitella praegemma, and Turborotalia cerroazulensis cocoaensis) occur within the interval sampled for this study (i.e., Sample 150-904A-45X-2, 74-96 cm; Fig. 3). The last occurrence of Subbotina linaperta, common to abundant throughout the sampled interval at Site 904, lies within Zone P15 at Site 612 (Miller et al., 1991), suggesting that the tektite-rich zone at Site 904 can be constrained to Zone P15.

Assignment of the tektite-rich zone at Site 904 to planktonic foraminifer Zone P15 agrees with its assignment to calcareous nannofossil Zone NP19-20. It also corroborates previous biostratigraphic interpretations conducted at Site 612 based on planktonic foraminifers (e.g., Miller et al., 1991; Poag and Aubry, 1995).

The zonal assignment discussed above is based on specimens interpreted to be indigenous. Allogenic specimens characteristic of the middle Eocene (e.g., Acarinina bullbrooki, Morozovella spinulosa, Truncorotaloides rohri), although few and somewhat sporadic, occur in most horizons sampled for this study (Fig. 3). Miller et al. (1991) found reworked middle Eocene planktonic foraminifera in and above the tektite layer at Site 612. Poag and Aubry (1995) noted numerous allogenic planktonic foraminifers and calcareous nannofossils as high as $39.4 \mathrm{~m}$ above the tektite layer at Site 612. At Site 904, allogenic planktonic foraminifers persist, often in greater abundance than within the tektite-bearing zone itself, upward for another $21.5 \mathrm{~m}$ (Snyder et al., this volume).

Benthic foraminifer assemblages across the tektite layer (415.65$415.85 \mathrm{mbsf}$ ) indicate middle to lower bathyal depths (600-2000 m). The faunas are consistent with in situ deposition. Only one shallowwater specimen was found: Elphidium spp. (generally found at water depths less than $100 \mathrm{~m}$ ) was noted at $415.78 \mathrm{mbsf}$. Benthic foraminifers on the tektite-yielding layer of Site 612 are also consistent with bathyal deposition with estimated paleodepths between 600 and 2000 m (Miller and Katz, 1987; Miller et al., 1991).

\section{DISCUSSION}

Mineralogical, major oxide, and biostratigraphic studies of Site 904 tektites and sediments related to their emplacement indicate that the tektite layer of Site 904 is correlative to that of Site 612 and to the Exmore breccia. The interval in which the Site 904 tektites occur has been assigned to planktonic foraminiferal Zone P15 and to calcareous nannofossil Zone NP19-20.

\section{Implications of Planktonic Foraminifer Biostratigraphy}

Planktonic foraminifer are most abundant in the portion of the sampled interval that lies below the tektite laminae. Specimens here are 1.5 to 9.5 times more abundant than in the overlying laminae, but the number of taxa is only slightly greater (Fig. 3). Indeed, when expressed in terms of the Shannon-Wiener Information Function displayed as $\mathrm{H}(\mathrm{S})$ on Figure 3, diversity in these lower layers is less than in the overlying laminae. Low values of this compound diversity index reflect that higher total abundances are produced by large numbers of a few taxa that numerically dominate the faunas.

Relative changes in the quality of preservation may be inferred from the percentage of unidentifiable specimens within the samples. Specimens herein categorized as unidentifiable include broken specimens (but not isolated single chambers) and specimens altered by dissolution to the point where taxonomically diagnostic features cannot be observed. The percentage of such specimens increases consistently upward through the interval (Fig. 3), culminating in Sample $150-904 \mathrm{~A}-45 \mathrm{X}-2,74-75 \mathrm{~cm}$, where only a few specimens escaped destruction.

The observed trend in the quality of preservation suggests that the entire 24-cm-thick interval may be responding as a single unit, in which the percentage of unidentifiable specimens reflects a diagenet- 


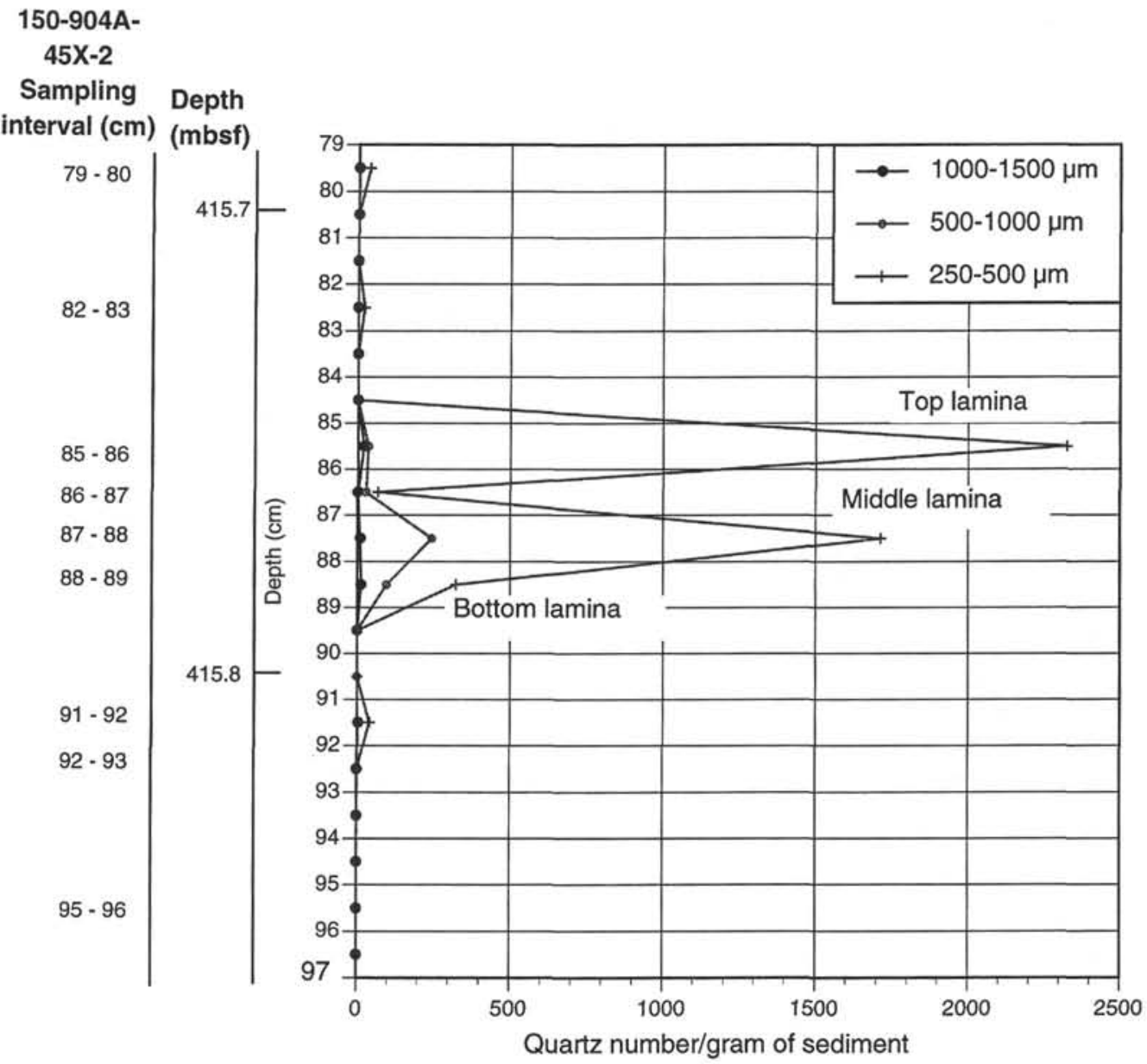

Figure 9. Grain-size distribution of quartz showing fining-upward trend. Interval $150-904 \mathrm{~A}-45 \mathrm{X}-2,79-96 \mathrm{~cm}$. Quartz is abundant in the middle and top laminae.

ic profile. The diagenesis of the foraminifers is associated with large abundances of pyrite that characterize the 24-cm-thick section and are especially abundant in Interval 150-904A-45X-2, 74-75 cm (Shipboard Scientific Party, 1994). Abundant pyrite is also associated at Site 612 with the tektite-bearing sediment. Keller et al. (1987) suggested that its occurrence was due to reducing conditions as a result of an influx of biologic matter which is also a possibility for Site 904.

Despite obvious changes in total abundance and quality of preservation upward through the sampled interval, the faunal similarity among the samples (except for the 74-75-cm interval) is striking and characteristic of the Eocene. Species richness, species diversity expressed by $\mathrm{H}(\mathrm{S})$, and the taxa that are present change very little throughout the sampled interval (Fig. 3). Changes in species composition result from the sporadic occurrences of rare taxa which reveal no trends or patterns.

\section{Significance of Clay Minerals}

Eocene clay sediments in the North Atlantic are dominated by smectite mainly reworked from soils developed on continental areas (Chamley, 1989; Deconinck and Vanderaveroet, this volume). During the Eocene, detrital inputs transported by rivers were reduced (Poag and Sevon, 1989). Smectites were probably transported by winds as suggested by Lever and McCave (1983). In the tektite layer, the differential thermal analyses indicate the occurrence of two types of smectite, suggesting the additional formation of smectite by sub- marine alteration of glass, as described in the Stevns Klint Cretaceous/Tertiary boundary layer in Denmark (Kastner et al., 1984). This interpretation is confirmed by the chemical composition of the clay fraction of Sample 150-904A-45X-2, 88-89 cm, in which smectites contain more magnesium and sodium coming from sea water. These smectites also contain less potassium, because they are less interstratified by illite.

\section{Implications of Grain-Size Distribution}

The grain-size distribution of Site 904 tektite-bearing layer indicates an overall fining-upward trend, which is consistent with gravity settling of the grains. Turbidity currents have been considered as a possible mechanism for the deposition of the tektite laminae. But because benthic foraminifer assemblages are in situ and their estimated paleodepths are 600 to $2000 \mathrm{~m}$, they argue against the possibility that the tektites were transported from shallow water by turbidity currents and related gravity-controlled flows. The abundance of planktonic foraminifers relative to benthic foraminifers is also consistent with bathyal biotopes. Benthic foraminifer assemblages of Site 612 are also bathyal and a shallow-water turbidite origin was ruled out for the deposition of Site 612 tektites (Miller et al., 1991; Miller and Katz, 1987). Therefore, transport by turbidity currents that originated near the shelf is not a likely depositional process.

Another characteristic of the tektite-bearing layer that argues against a turbidity current origin is the concentration of tektites and mineral grains into three distinct layers. The dominantly coarse- and 


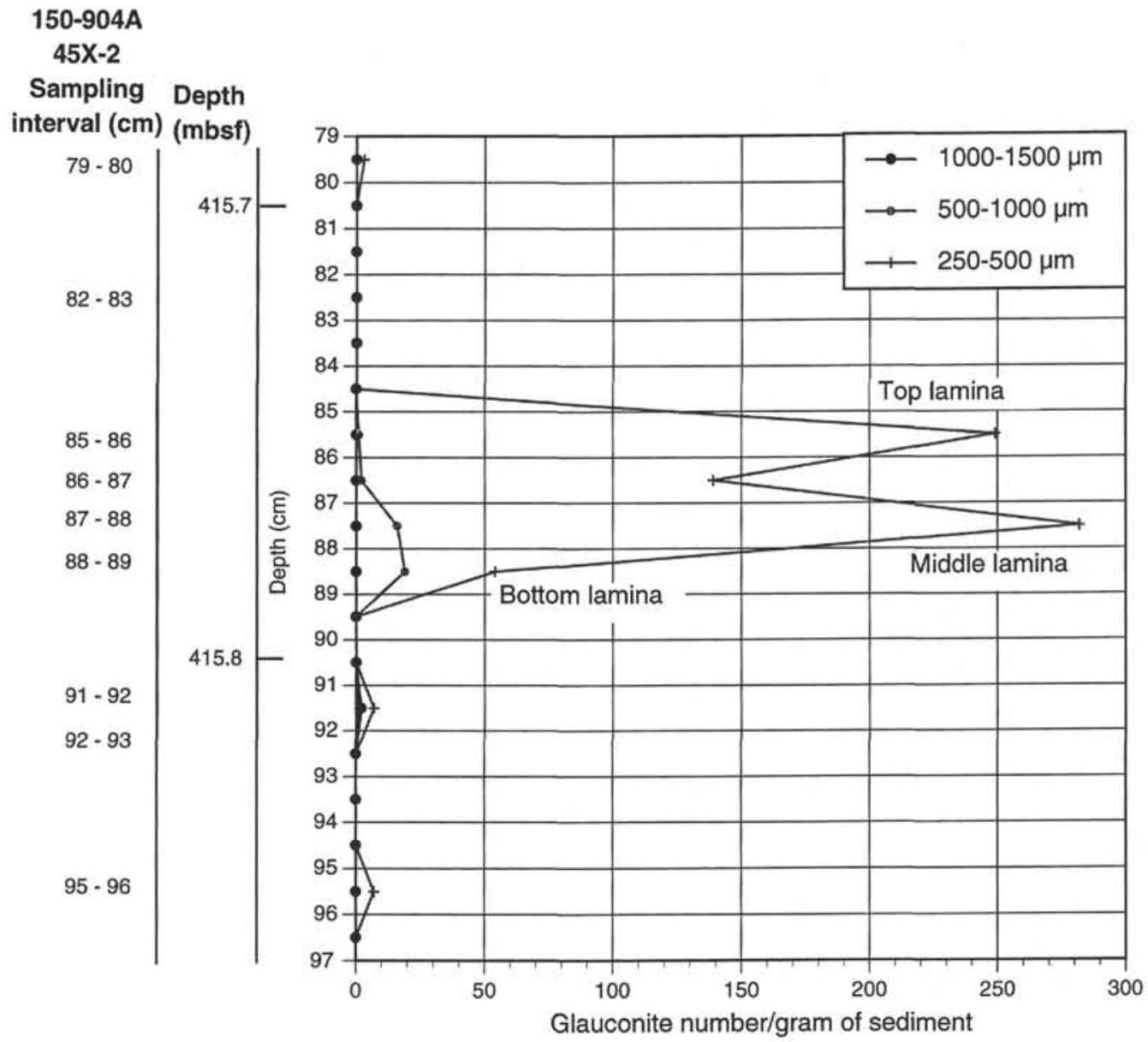

Figure 10. Grain-size distribution of glauconite also shows a fining-upward trend. Glauconite samples from Interval 150-904A-45X-2, 79-96 cm. Glauconite occurs in most sampled intervals.

fine-grained fractions occur in the bottom and top layers, respectively, so that the fining-upward trend is observed in the sequence as a whole, not in the individual laminae. Normal grading within each lamina, which is not apparent, would be more in agreement with a turbidity current origin. Settling of the grains through the water column is consistent with the observed overall fining-upward trend. The coarse-grained components settled first and the fine-grained components settled last in the bottom and top of the sequence, respectively.

A potential problem with invoking gravitational settling of grains as a depositional mechanism is that at Site 904 the bottom and middle layers have a similar grain-size distribution and should have been deposited concurrently. However, they are separated by a $\sim 1-\mathrm{cm}$-thick clay interval. Another problem is that the unmelted ejecta is most abundant in the middle and top laminae than in the bottom lamina. A possibility to explain the occurrence of clay in between the bottom and top laminae is that there was a continuous rain of the ejecta with pulses of clay sliding through an unstable seafloor as a result of impact-generated disturbances. This is supported by the following: (1) abundant tektites of a similar grain size as the bottom and middle laminae are contained in the clay interval that separates the two layers, (2) tektites occur throughout the 5-cm-thick interval (Interval $150-904 \mathrm{~A}-45 \mathrm{X}-2,84.5-89.5 \mathrm{~cm}$ ), and (3) there is evidence of sediment failure above and below the tektite bearing sediment.

Another possibility is that there were pulses of deposition within the overall interval. Experimental and theoretical studies have shown that the ejecta that results from an impact event is distributed at dif- ferent angles and velocities (O' Keefe and Aherns, 1982; Evans et al., 1994). It is possible that the ejecta followed different trajectories which led to the deposition of the laminae and to the peak concentrations of mineral grains. This possibility would explain the concentration of the unmelted ejecta in the middle and top laminae. It would be difficult to explain the depositional relations of the tektite-bearing interval, the fining-upward grain-size distribution, narrow range in major oxide composition, and diagenetic profile of the tektite-bearing layer as three separate impact events unless three events occurred in the same general area and they occurred closely together in time.

Alternative explanations could be a bolide that broke into several pieces or a shower of meteorites, all falling within the general region. Our interpretation of the deposition of Site 904 tektite layers by gravity settling supports Glass (1989) interpretation that the Site 612 tektites were deposited as a result of successive airfalls. However, because there is evidence of sediment deformation above and below the tektite laminae, we do not preclude the possibility that small-scale slope failures could have displaced the sediment from nearby bathyal biotopes.

\section{Major Oxide Chemistry: One or Two Impacts?}

The major oxide chemistry of Site 904 tektites from all analyzed intervals (415.93-415.75 mbsf), except for one point, shows a narrow range in composition. These results indicate a single source for the origin of the tektites. At Site 612 tektites occur throughout the tektite- 


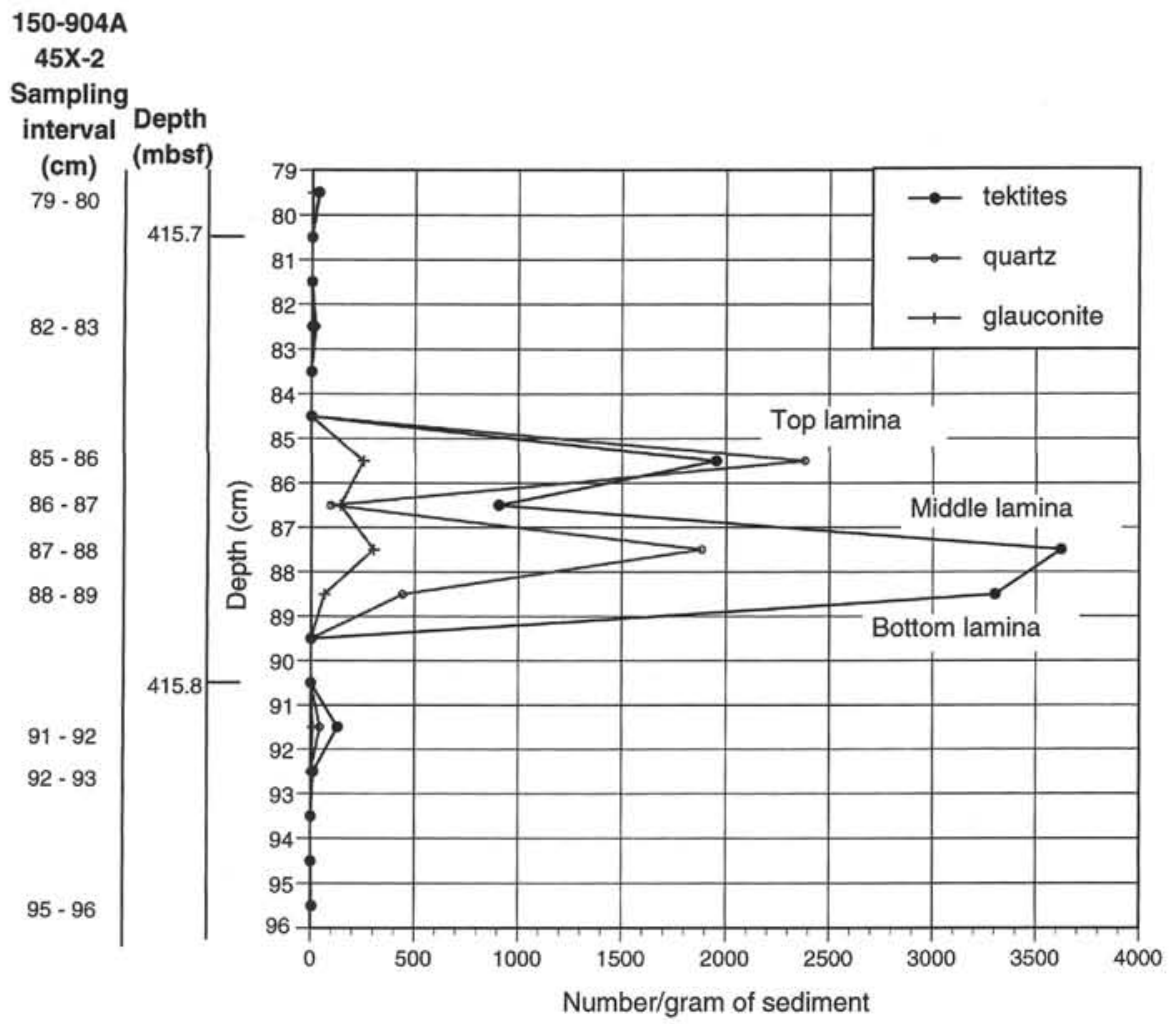

Figure 11. Abundances of tektites, quartz, and glauconite $(250-1500 \mu \mathrm{m})$ from Interval $150-904 \mathrm{~A}-45 \mathrm{X}-2,79-96 \mathrm{~cm}$. Tektites are more abundant in the lower and middle laminae than in the top. Quartz and glauconite are more abundant in the middle and top laminae than in the bottom lamina.

Table 3. X-ray diffractometry results.

\begin{tabular}{lccc}
\hline $\begin{array}{c}\text { Core, section, } \\
\text { interval }(\mathrm{cm})\end{array}$ & mlite & \multicolumn{2}{c}{ Smectite Kaolinite } \\
\hline 150-904A- & & & \\
$45 \mathrm{X}-2,52-53$ & 2 & 96 & 2 \\
$45 \mathrm{X}-2,68-69$ & 3 & 93 & 4 \\
$45 \mathrm{X}-2,74-75$ & 3 & 93 & 4 \\
$45 \mathrm{X}-2,79-80$ & 2 & 95 & 3 \\
$45 \mathrm{X}-2,82-83$ & 3 & 94 & 3 \\
$45 \mathrm{X}-2,85-86$ & 2 & 96 & 2 \\
$45 \mathrm{X}-2,86-87$ & 2 & 95 & 3 \\
$45 \mathrm{X}-2,87-88$ & 1 & 97 & 2 \\
$45 \mathrm{X}-2,88-89$ & 1 & 97 & 2 \\
$45 \mathrm{X}-2,91-92$ & 3 & 92 & 5 \\
$45 X-2,92-93$ & 5 & 86 & 9 \\
$45 X-2,95-96$ & 4 & 90 & 6 \\
$45 X-2,109-110$ & 4 & 90 & 6 \\
$45 X-2,120-121$ & 6 & 87 & 7 \\
\hline
\end{tabular}

bearing horizon and have similar major oxide chemistry as the Site 904 tektites (Glass, 1989). The tektite fragments at Site 612, occur in greater abundances $(\sim 10$ to 15 times more abundant) than the microtektites and microkrystites that are concentrated in the upper and bottom sections of the interval, respectively (Glass, 1989). Glass (1989) indicated that the tektites and microtektites at Site 612 are from a single event. However, Glass (1989) suggested that because of the spatial distribution of microkrystites and microtektites at Site 612 , and due to the fact that the layers are separated by an $\sim 4-\mathrm{cm}-$ thick interval, the microkrystites probably originated from a different, older event. We suggest that Site 904 and correlative Site 612 tektites were deposited as a result of one event. Our interpretation is based on the following facts: (1) major oxide analyses of the Site 904 tektites, (2) depositional relations of the tektite laminae and of the tektite-bearing interval at Site 904, (3) grain-size distribution of the tektites and mineral grains at Site 904, (4) diagenetic profile of Site 904 planktonic foraminifers that indicates that the tektite-bearing interval responded as a single unit, (5) the range in major oxide composition of the tektite fragments at Site 612, and (6) the fact that the Site 612 tektite fragments are the most abundant component at all intervals of the tektite-bearing layer. The concentration of microkrystites near the bottom of the Site 612 tektite interval possibly resulted from processes related to the distribution and deposition of the ejecta. The broader range in major oxide composition of the microtektites and microkrystites at Site 612 is attributed to the melting of a variety of rocks in a heterogeneous source. Isotopic studies of Site 612 tektites also suggest that the source of the tektites was heterogeneous. Stecher et al. (1989) analyzed $\mathrm{Nd}$ and $\mathrm{Sr}$ isotopes of several tektites from Site 612 and found that one sample has $\mathrm{Sr}$ and $\mathrm{Nd}$ isotopic values that suggest it had a different origin than the other tektites.

Stecher et al. (1989) also compared the $\mathrm{Nd}$ and $\mathrm{Sr}$ isotopic values of the Site 612 tektites to those of tektites belonging to the North American strewn field. They concluded that the Site 612 tektites have a higher proportion of an older crustal component and that they have a different source than the North American strewn field, but that despite these differences they both had to originate from the eastern and southeastern North American continent or shelf from rocks derived from the Appalachian orogen. Stecher et al. (1989) proposed that the differences between Site 612 and the North American strewn field could result from (1) one or more impacts in the same general area, or (2) from a single impact that penetrated a chemically and isotopically heterogeneous source.

Poag et al. (1992, 1994b) and Poag and Aubry (1995) proposed that the Site 612 tektites and the tektites from the North American strewn field originated from separate but coincident bolide impacts. Poag et al. (1992) and Poag and Aubry (1995) proposed that a small 
Section 150-904A-45X-2

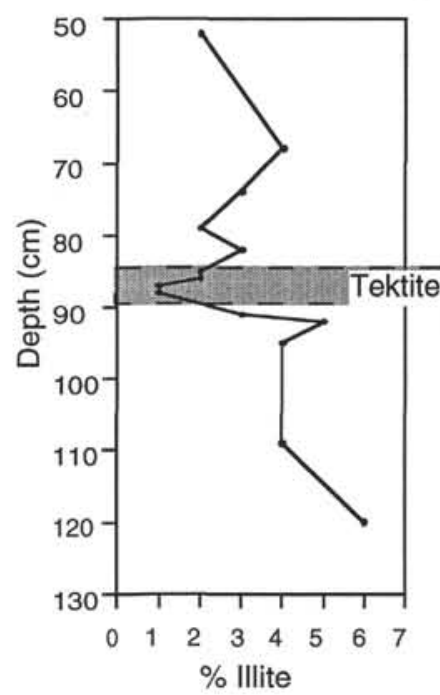

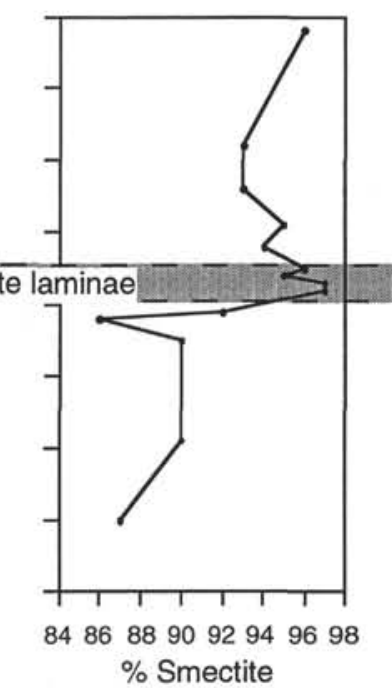

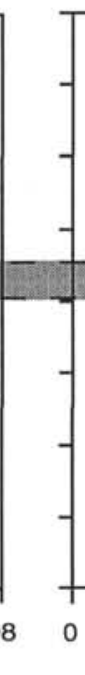

Figure 12. Clay mineralogy of sediments across the tektite interval, Section 150-904A-45X-2.
Table 4. Comparison of chemical analyses of the clay fraction from a tektite layer and adjacent layers.

\begin{tabular}{lllllllll}
\hline $\begin{array}{c}\text { Core, section, } \\
\text { interval }(\mathrm{cm})\end{array}$ & $\mathrm{SiO}_{2}$ & $\mathrm{Al}_{2} \mathrm{O}_{3}$ & $\mathrm{Fe}_{2} \mathrm{O}_{3}$ & $\mathrm{MgO}$ & $\mathrm{TiO}_{2}$ & $\mathrm{~K}_{2} \mathrm{O}$ & $\mathrm{CaO}$ & $\mathrm{Na}_{2} \mathrm{O}$ \\
\hline $150-904 \mathrm{~A}-$ & & & & & & & & \\
$45 \mathrm{X}-2,52-53$ & 72.33 & 15.85 & 4.94 & 2.92 & 0.51 & 1.45 & 1.15 & 0.85 \\
$45 \mathrm{X}-2,88-89$ & 67.07 & 21.09 & 4.61 & 3.77 & 0.59 & 1.00 & 0.36 & 1.51 \\
$45 \mathrm{X}-2,109-110$ & 71.09 & 16.63 & 4.92 & 3.12 & 0.47 & 1.84 & 1.36 & 0.57 \\
\hline
\end{tabular}

structure near the head of Toms Canyon on the New Jersey continental shelf is the source of the Site 612 tektites. Their proposed "impact crater" is $40 \mathrm{~km}$ north-northwest of Site $612,200-500 \mathrm{~m}$ deep, $15 \times$ $25 \mathrm{~km}$ wide, and penetrated Paleocene to upper Eocene carbonates and Cretaceous siliciclastic sediment. It has been established that the geochemistry of tektites provides information about the source rocks from which the tektites originated (Koeberl, 1986; Glass, 1990). Glasses derived from a predominately calcium-rich source such as the chalks and limestones of the New Jersey continental shelf should contain a higher $\mathrm{CaO}$ content than the Site 904 tektites which average $0.87 \mathrm{CaO}$ wt\% with a standard deviation of 0.63 .

Microkrystites of Site 612 contain $\mathrm{CaO}$ values that are higher than the tektites and microtektites of Site 904 and 612. Microkrystites of Site 612 average $5.60 \mathrm{CaO}$ wt \% and have a standard deviation for $\mathrm{CaO}$ of 2.87 (Glass, 1989). These $\mathrm{CaO}$ values are not high enough to explain a carbonate-rich source. In addition, microkrystites when compared to the tektite fragments at Site 612 and the tektites of Site 904 not only have higher $\mathrm{CaO}$ but also higher $\mathrm{MgO}$ and $\mathrm{FeO}$ and lower $\mathrm{SiO}_{2}, \mathrm{Al}_{2} \mathrm{O}_{3}$, and $\mathrm{TiO}_{2}$. The melting of a carbonate-rich source should produce glasses in which $\mathrm{CaO}$ and $\mathrm{MgO}$ increase inversely to $\mathrm{SiO}_{2}$, but it would not be expected for $\mathrm{FeO}$ to increase. Sigurdsson et al. (1991) conducted studies on the major oxide composition of the Beloc glasses preserved at the Cretaceous/Tertiary boundary at Beloc, Haiti. Results of these studies showed that a yellow glass found in the Beloc layer was attributed to the melting of carbonate- or sulfate-rich evaporites in the presence of andesite. These glasses contain up to $30 \mathrm{wt} \% \mathrm{CaO}$. The Haiti glasses show an inverse correlation with $\mathrm{SiO}_{2}$ in which $\mathrm{CaO}$ and $\mathrm{MgO}$ increase, but not $\mathrm{FeO}$ (Sigurdsson, 1991). According to Sigurdsson et al. (1991) the geochemistry of the Haiti glasses matches the lithologies found in the $180 \mathrm{~km}$ Chicxulub structure that occurs in the Cretaceous evaporite deposits in Mexico.

Extensive vaporization of the target rock in the ejecta plume cannot explain the absence of $\mathrm{CaO}$ at Site 904 and 612. However, Sig- urdsson et al. (1991) showed that during decompression following a high-velocity impact, the shocked crustal material is mainly liquid. Because there is not sufficient $\mathrm{CaO}$ in the tektites of Sites 904 and 612 , Toms Canyon "impact crater" is not considered to be a likely source for the glasses.

Poag et al. (1994b) and Poag and Aubry (1995) proposed that a structure located beneath Chesapeake Bay is an "impact crater" and the source for the North American strewn field. This "impact crater" is $85 \mathrm{~km}$ in diameter and excavated 1 to $1.5 \mathrm{~km}$ into Precambrian and Paleozoic basement (metasedimentary and granitic rocks) and Lower Cretaceous to upper Eocene sediment. The major oxide composition of tektites from Sites 904 and 612, as well as the geochemical signature of ejecta from Site 612, correlate with an Appalachian siliciclastic source and with the target rocks of the Chesapeake Bay "crater." Major oxide composition of tektites from Sites 904 and 612 also correlate with the North American strewn field. The low sodium and high potassium content of tektites from Sites 904 and 612 might be related to the fact that these tektites are closer to the "impact crater" and may have originated from deeper stratigraphic horizons than the North American strewn field.

The Chesapeake Bay structure is a possible source for the ejecta from Sites 904 and 612 and for the North American strewn field. The Chesapeake Bay structure as a source crater is consistent with a single impact event that excavated diverse rock types with chemically and isotopically heterogeneous signatures.

\section{Interpretation of the Tektites' Depositional History}

During the Eocene, the U.S. middle Atlantic margin (New JerseyDelaware-Maryland) was a gradually subsiding passive margin with a gentle slope and slowly accumulating pelagic sediment (Watts and Steckler, 1979; Poag and Mountain, 1987). This environment was disturbed during the late Eocene by the impact of a large extraterrestrial body. According to Poag et al. (1994a) the Chesapeake Bay impact had devastating consequences for the surrounding environment: $\sim 2000 \mathrm{~km}^{3}$ of rock were removed, the impact crater was filled at synimpact depositional rates of more than $1.5 \mathrm{~km} / \mathrm{min}$, and a tsunamilike wave train was generated. Theoretical studies by O'Keefe and Aherns (1982) provided a mechanism for the formation of tektites that can be applied to the late Eocene impact event. According to O'Keefe and Aherns (1982), upward-directed flow fields resulting from an impact entrain the melted and condensed particles, cooled them, ejected them, and distributed the tektites into strewn fields. The upward-moving air flows follow different trajectories and can 
Table 5. Major oxide composition of Site 904 tektites listed by size, interval, and sample number.

\begin{tabular}{|c|c|c|c|c|c|c|c|c|c|c|c|}
\hline $\begin{array}{c}\text { Size } \\
\text { Interval }(\mathrm{cm}) \\
\text { Sample number* }\end{array}$ & $\begin{array}{c}\mathrm{SiO}_{2} \\
\text { (wt\%) }\end{array}$ & $\begin{array}{l}\mathrm{Al}_{2} \mathrm{O}_{3} \\
\text { (wt\%) }\end{array}$ & $\begin{array}{l}\mathrm{FeO} \\
\text { (wt\%) }\end{array}$ & $\begin{array}{l}\mathrm{MgO} \\
(\mathrm{wt} \%)\end{array}$ & $\begin{array}{l}\mathrm{CaO} \\
\text { (wt\%) }\end{array}$ & $\begin{array}{l}\mathrm{Na}_{2} \mathrm{O} \\
(\mathrm{wt} \%)\end{array}$ & $\begin{array}{c}\mathrm{K}_{2} \mathrm{O} \\
\text { (wt\%) }\end{array}$ & $\begin{array}{l}\mathrm{TiO}_{2} \\
(\mathrm{w} t \%)\end{array}$ & $\begin{array}{l}\mathrm{MnO} \\
(\mathrm{w} t \%)\end{array}$ & $\begin{array}{l}\mathrm{P}_{2} \mathrm{O}_{5} \\
(\mathrm{wt} \%)\end{array}$ & $\begin{array}{l}\text { Total } \\
\text { (wt\%) }\end{array}$ \\
\hline \multicolumn{12}{|l|}{$\begin{array}{c}150-904 \mathrm{~A}-45 \mathrm{X}-2 \\
0-1500 \mu \mathrm{m}\end{array}$} \\
\hline $85-86,5(4)$ & 75.47 & 13.19 & 4.02 & 1.03 & 0.88 & 0.65 & 2.79 & 0.80 & 0.02 & 0.02 & 98.86 \\
\hline $85-86,4(4)$ & 71.99 & 15.01 & 4.46 & 1.18 & 1.12 & 1.32 & 2.81 & 0.80 & 0.02 & 0.05 & 98.77 \\
\hline $\begin{array}{l}500-1000 \mu \mathrm{m} \\
85-86,2(3)\end{array}$ & 77.30 & 12.60 & 3.88 & 0.89 & 0.40 & 0.11 & 2.64 & 0.72 & 0.07 & 0.00 & 98.60 \\
\hline $85-86,3(3)$ & 77.10 & 12.20 & 3.86 & 0.92 & 0.56 & 0.22 & 2.61 & 0.71 & 0.07 & 0.00 & 98.27 \\
\hline $85-86,1(4)$ & 74.60 & 13.50 & 4.42 & 1.19 & 1.01 & 0.57 & 2.75 & 0.74 & 0.07 & 0.04 & 98.86 \\
\hline $85-86,4(3)$ & 73.30 & 14.60 & 4.25 & 1.10 & 1.00 & 0.88 & 2.69 & 0.74 & 0.08 & 0.00 & 98.64 \\
\hline $\begin{array}{l}500-1000 \mu \mathrm{m} \\
86-87,1(4)\end{array}$ & & & & & & & & & & & \\
\hline $\begin{array}{l}86-87,1(4) \\
86-87,2(3)\end{array}$ & $\begin{array}{l}77.60 \\
77.50\end{array}$ & $\begin{array}{l}12.50 \\
12.30\end{array}$ & $\begin{array}{l}4.08 \\
4.01\end{array}$ & $\begin{array}{l}0.95 \\
0.99\end{array}$ & 0.42 & $\begin{array}{l}0.14 \\
0.19\end{array}$ & $\begin{array}{l}2.66 \\
2.66\end{array}$ & 0.72 & 0.06 & 0.03 & $\begin{array}{l}99.13 \\
9901\end{array}$ \\
\hline $86-87,4(3)$ & 76.70 & 12.70 & 4.25 & 1.08 & 0.80 & 0.32 & 2.74 & 0.77 & 0.09 & 0.00 & 99.49 \\
\hline $86-87,3(3)$ & 76.50 & 12.80 & 4.34 & 1.09 & 0.72 & 0.30 & 2.86 & 0.74 & 0.06 & 0.05 & 99.49 \\
\hline $1000-1500 \mu \mathrm{m}$ & & & & & & & & & & & \\
\hline $87-88,2(4)$ & 77.65 & 12.42 & 3.91 & 0.96 & 0.58 & 0.29 & 2.63 & 0.81 & 0.03 & 0.02 & 99.31 \\
\hline $87-88,5(4)$ & 76.36 & 12.45 & 4.15 & 1.06 & 0.87 & 0.44 & 2.73 & 0.77 & 0.03 & 0.02 & 98.87 \\
\hline $87-88,4$ (4) & 75.25 & 13.53 & 4.07 & 1.03 & 0.90 & 0.89 & 2.90 & 0.78 & 0.03 & 0.03 & 99.42 \\
\hline $87-88,3(4)$ & 73.19 & 14.31 & 4.50 & 1.32 & 1.28 & 1.14 & 2.64 & 0.80 & 0.03 & 0.03 & 99.24 \\
\hline $87-88,6(3)$ & 70.50 & 12.30 & 5.76 & 1.26 & 0.83 & 0.37 & 2.46 & 0.72 & 0.08 & 0.07 & 94.33 \\
\hline $500-1000 \mu \mathrm{m}$ & & & & & & & & & & & \\
\hline $87-88,6(3)$ & 79.10 & 11.80 & 3.84 & 0.88 & 0.46 & 0.18 & 2.50 & 0.71 & 0.11 & 0.00 & 99.66 \\
\hline $87-88,8$ (3) & 74.40 & 14.40 & 4.44 & $\begin{array}{l}1.20 \\
1.20\end{array}$ & 1.04 & 0.87 & 2.74 & 0.74 & 0.09 & 0.01 & 100.00 \\
\hline $87-88,7$ (3) & 73.60 & 14.30 & 4.48 & 1.22 & 1.08 & 1.35 & 2.75 & 0.74 & 0.07 & 0.04 & 99.63 \\
\hline $87-88,5(3)$ & 73.10 & 14.80 & 4.42 & 1.21 & 1.07 & 0.96 & 2.63 & 0.78 & 0.10 & 0.00 & 99.06 \\
\hline $87-88,2$ (3) & 73.10 & 14.30 & 4.33 & 1.19 & 1.00 & 0.92 & 2.79 & 0.74 & 0.08 & 0.01 & 98.46 \\
\hline $87-88,3$ (3) & 70.50 & 12.30 & 2.42 & 0.86 & 1.79 & 2.05 & 2.79 & 0.40 & 0.08 & 0.00 & 93.22 \\
\hline $1000-1500 \mu \mathrm{m}$ & & & & & & & & & & & \\
\hline $88-89,2(7)$ & 76.40 & 12.93 & 4.26 & 1.13 & 0.88 & 0.44 & 2.72 & 0.82 & 0.06 & 0.03 & 98.87 \\
\hline $88-89,1(5)$ & 74.23 & 14.28 & 4.72 & 1.22 & 0.74 & 0.41 & 3.17 & 0.85 & 0.06 & 0.04 & 98.89 \\
\hline $88-89,3$ (4) & 72.07 & 15.29 & 5.07 & 1.35 & 1.01 & 0.59 & 3.37 & 0.92 & 0.06 & 0.02 & 98.87 \\
\hline $88-89,7(3)$ & 71.60 & 11.90 & 4.03 & 0.96 & 0.56 & 0.25 & 2.50 & 0.68 & 0.09 & 0.07 & 92.67 \\
\hline $88-89,4(6)$ & 70.85 & 14.73 & 4.90 & 1.36 & 1.08 & 0.61 & 3.64 & 0.88 & 0.05 & 0.10 & 97.32 \\
\hline $88-89,5(6)$ & 69.09 & 1.15 & 0.11 & 3.84 & 6.07 & 11.88 & 1.25 & 0.03 & 0.01 & 0.02 & 93.42 \\
\hline $500-1000 \mu \mathrm{m}$ & & & & & & & & & & & \\
\hline $88-89,1$ (3) & 75.20 & 13.30 & 4.20 & 1.01 & 0.65 & 0.40 & 2.81 & 0.81 & 0.08 & 0.01 & 98.44 \\
\hline $88-89,10(3)$ & 75.20 & 12.90 & 4.33 & 1.04 & 0.59 & 0.38 & 2.75 & 0.75 & 0.05 & 0.04 & 98.06 \\
\hline $88-89,94)$ & 73.90 & 13.90 & 4.03 & 1.10 & 0.88 & 0.88 & 2.89 & 0.73 & 0.09 & 0.01 & 98.41 \\
\hline $88-89,3(3)$ & 73.80 & 13.70 & 4.40 & 1.11 & 0.93 & 0.87 & 2.89 & 0.70 & 0.06 & 0.00 & 98.45 \\
\hline $88-89,7$ (3) & 72.70 & $\begin{array}{l}15.20 \\
-10\end{array}$ & 4.24 & 1.14 & 1.03 & 0.95 & 2.63 & 0.76 & 0.09 & 0.01 & 98.80 \\
\hline $88-89,5(3)$ & 72.10 & 14.90 & 4.95 & $\begin{array}{l}1.29 \\
1.29\end{array}$ & 0.87 & 0.51 & 3.23 & 0.83 & 0.09 & 0.03 & 98.72 \\
\hline $88-89,2$ (4) & 71.10 & 15.50 & 4.85 & 1.21 & 0.68 & 0.53 & 3.68 & 0.79 & 0.09 & 0.02 & 98.42 \\
\hline $88-89,8(4)$ & 70.80 & 14.20 & 4.77 & 1.48 & 1.31 & 0.86 & 3.27 & 0.80 & 0.09 & 0.06 & 97.66 \\
\hline $\begin{array}{l}1000-1500 \mu \mathrm{m} \\
91-92,4(4)\end{array}$ & 76.80 & 11.60 & 3.68 & 0.85 & 0.41 & 0.12 & 2.45 & 0.67 & 0.05 & 0.00 & 96.67 \\
\hline $500-1000 \mu \mathrm{m}$ & & & & & & & & & & & \\
\hline $91-92,1(3)$ & 78.10 & 11.70 & 3.90 & 0.87 & 0.39 & 0.12 & 2.55 & 0.68 & 0.08 & 0.02 & 98.41 \\
\hline $91-92,2(3)$ & 77.20 & 12.80 & 3.92 & 0.94 & 0.43 & 0.12 & 2.45 & 0.76 & 0.08 & 0.00 & 98.67 \\
\hline $91-92,3(3)$ & 77.10 & 12.40 & 4.02 & 0.95 & 0.47 & 0.26 & 2.47 & 0.72 & 0.10 & 0.00 & 98.56 \\
\hline $\begin{array}{l}500-1000 \mu \mathrm{m} \\
92-93,1(3)\end{array}$ & 78.90 & 12.00 & 2.09 & 0.45 & 0.68 & 0.54 & 2.42 & 0.37 & 0.05 & 0.00 & 97.52 \\
\hline $102-103.7(4)$ & 74.10 & 12.20 & 3.68 & 0.98 & 0.70 & 0.48 & 2.59 & 0.70 & 0.06 & 0.00 & 95.52 \\
\hline $102-103,2$ (4) & 73.95 & 14.12 & 4.60 & $\begin{array}{l}.30 \\
1.19\end{array}$ & 0.66 & 0.38 & 3.03 & 0.82 & 0.10 & 0.02 & 98.90 \\
\hline $102-103,4(4)$ & 71.90 & 12.33 & 3.85 & 0.97 & 0.50 & 0.38 & 2.81 & 0.70 & 0.05 & 0.01 & 93.52 \\
\hline $102-103,5(4)$ & 71.22 & 13.47 & 4.04 & 1.12 & 0.58 & 0.36 & 2.77 & 0.75 & 0.07 & 0.03 & 94.42 \\
\hline $102-103,1$ (4) & 70.63 & 13.97 & 4.55 & 1.16 & 0.65 & 0.45 & 2.97 & 0.77 & 0.04 & 0.01 & 95.20 \\
\hline $102-103,3(4)$ & 66.59 & 13.75 & 4.30 & 1.14 & 0.64 & 0.55 & 3.16 & 0.75 & 0.06 & 0.03 & 90.99 \\
\hline Standard deviation & 2.81 & 1.83 & 0.78 & 0.37 & 0.63 & 1.21 & 0.35 & 0.13 & 0.02 & 0.02 & 1.97 \\
\hline Average & 74.09 & 13.14 & 4.12 & 1.13 & 0.87 & 0.77 & 2.78 & 0.73 & 0.07 & 0.02 & 97.54 \\
\hline
\end{tabular}

Notes: *Following each interval given in centimeters is the number assigned to the sample in this study. The number in parentheses refers to the number of analyses.

achieve velocities of up to $10 \mathrm{~km} / \mathrm{s}$. The entrained ejecta particles of less than $1 \mathrm{~cm}$ can reach altitudes that are greater than $10 \mathrm{~km}$. If Chesapeake Bay, located approximately $300 \mathrm{~km}$ away from the New Jersey continental slope, was where an impact occurred, as proposed by Poag et al. (1994b), then the tektites must have been transported to the upper atmosphere at hypervelocity in just a few seconds. The energy released by the impact must have been transmitted through the seafloor as shock waves and through the ocean waters as tsunami waves. The large volume of rock excavated from the crater and its rapid deposition must have generated clouds of dust and currents that stirred the seafloor for hundreds of kilometers away from the impact site. These events occurred as the ejecta debris settled on the New Jersey continental slope.
The laminated character of some of the tektite-bearing intervals (415.78-415.77 mbsf and 415.74-415.68 mbsf), as well as the soft sediment deformation features (415.68-415.63 mbsf) and breccia deposit that occur beneath the major concentration of tektites (415.98$415.81 \mathrm{mbsf}$ ) at Site 904, indicate that deposition of the ejecta on the New Jersey continental slope was influenced by mass-wasting and gravity-flow processes. These processes are interpreted to have occurred as a result of seafloor and water-column disturbances by tsunami and impact-generated shock waves. Calculations were made to estimate the time it would take for the particles ejected by the impact to reach a hypothetical altitude of $5 \mathrm{~km}$ and to settle through $5 \mathrm{~km}$ of air and $1 \mathrm{~km}$ of seawater, and for the tsunami and seismic impactgenerated waves to arrive to Site 904 (Table 2). The paleodepth for 

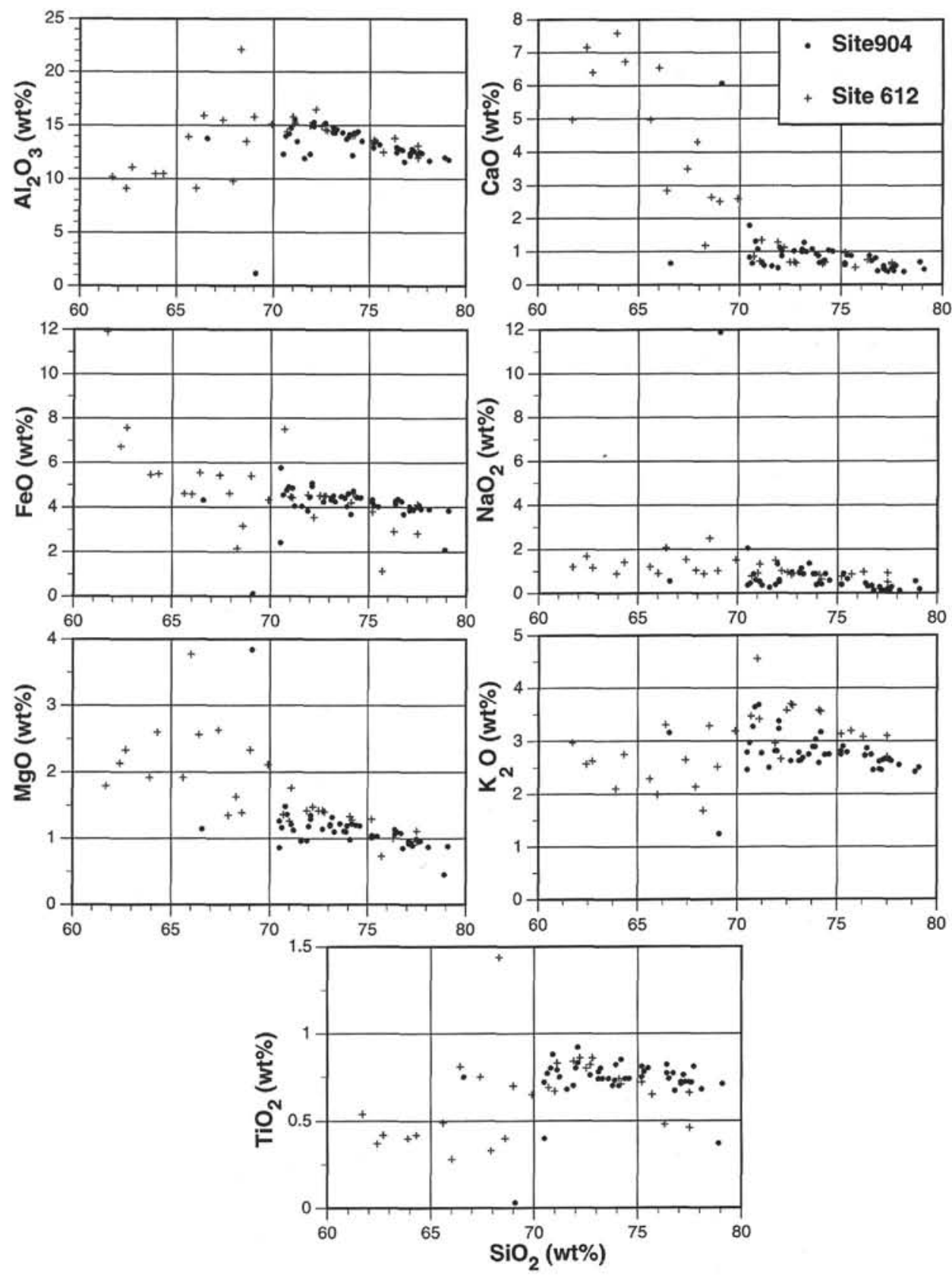

Figure 13. Major oxides vs. silica for Site 904 tektites (circles), and Site 612 tektites, microtektites, and microkrystites (crosses). Site $612 \mathrm{SiO}{ }_{2}$ weight percentage ranges are as follows: tektites $=69.9-77.5 \mathrm{wt} \%$, microtektites $=66.4-75.7 \mathrm{wt} \%$, and microkrystite $=61.7-67.9 \mathrm{wt} \%$. (Data points for Site $612 \mathrm{obtained}$ from Glass, 1989.)

Table 6. Major oxide compositional data of tektites from the North American strewn field.

\begin{tabular}{lcccccc}
\hline $\begin{array}{c}\text { Major oxide } \\
(\text { wt\%) }\end{array}$ & $\begin{array}{c}\text { Barbados } \\
\text { Range (18) }\end{array}$ & $\begin{array}{c}\text { Bediasites } \\
\text { Range (30) }\end{array}$ & $\begin{array}{c}\text { Georgianites } \\
\text { Range (8) }\end{array}$ & $\begin{array}{c}\text { Site 612 } \\
\text { tektites and } \\
\text { microtektites } \\
\text { Range (8) }\end{array}$ & $\begin{array}{c}\text { Site 904 } \\
\text { tektites } \\
\text { Range (50) }\end{array}$ & $\begin{array}{c}\text { Site 612 } \\
\text { microkrystites } \\
\text { Range (20) }\end{array}$ \\
\hline $\mathrm{SiO}_{2}$ & $76.90-85.60$ & $71.90-80.20$ & $79.80-83.60$ & $71.00-77.80$ & $66.60-78.90$ & $55.20-67.90$ \\
$\mathrm{Al}_{2} \mathrm{O}_{3}$ & $7.97-14.8$ & $11.20-17.60$ & $9.50-11.70$ & $13.00-15.10$ & $11.60-15.10$ & $7.78-13.30$ \\
$\mathrm{FeO}$ & $1.37-3.98$ & $2.29-5.75$ & $1.83-3.14$ & $2.70-5.00$ & $3.68-5.76$ & $1.31-11.90$ \\
$\mathrm{MgO}$ & $0.13-1.13$ & $0.37-0.98$ & $0.37-0.69$ & $0.70-1.40$ & $0.45-1.48$ & $1.35-5.27$ \\
$\mathrm{CaO}$ & $0.52-0.87$ & $0.35-0.96$ & $0.40-0.69$ & $0.80-1.00$ & $0.40-1.31$ & $1.01-8.33$ \\
$\mathrm{~N}_{2} \mathrm{O}$ & $1.15-1.52$ & $1.20-1.98$ & $1.00-1.53$ & $0.20-0.60$ & $0.11-2.05$ & $0.79-2.02$ \\
$\mathrm{~K}_{2} \mathrm{O}$ & $1.73-2.54$ & $1.42-2.43$ & $2.22-2.51$ & $3.00-3.80$ & $1.25-3.68$ & $1.93-3.61$ \\
$\mathrm{TiO}_{2}$ & $0.40-0.71$ & $0.59-1.05$ & $0.42-0.60$ & $0.55-0.85$ & $0.03-0.92$ & $0.18-0.54$ \\
\hline
\end{tabular}

Note: Data after compilations by Koeberl (1988), Koeberl and Glass (1988), and Glass (1989). 


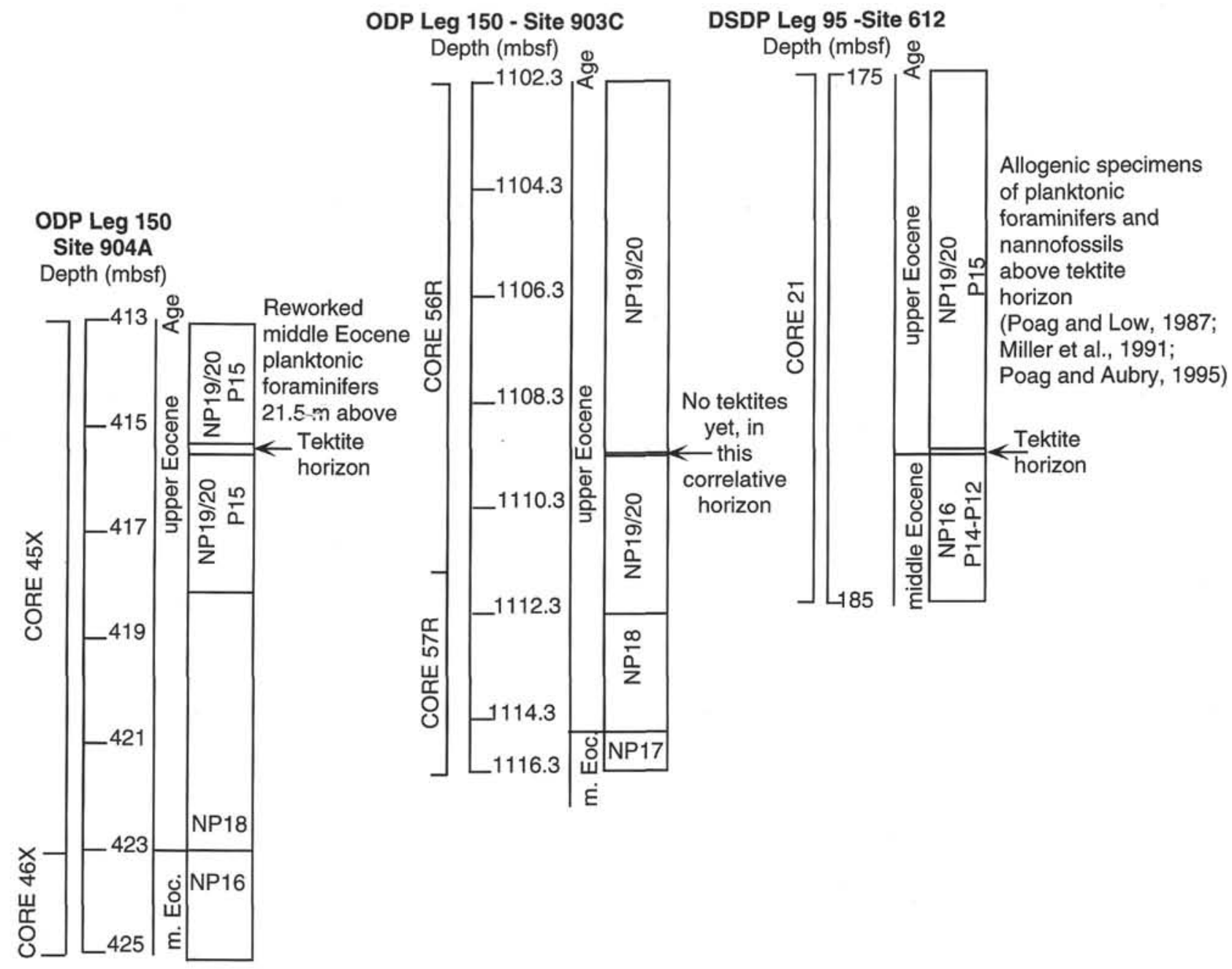

Figure 14. Biostratigraphy of Holes 904A and 903C and Site 612 near the tektite-bearing horizon. Note large unconformity beneath the tektite layer at Site 612. At Site 904 a smaller unconformity occurs $8 \mathrm{~m}$ below the tektite horizon.

Site 904 during the Eocene was estimated at $\sim 1000-1100 \mathrm{~m}$ (Katz and Miller, this volume). Based on these calculations and observations from the sedimentary record, a possible sequence of events is proposed for the deposition of the tektites.

Shock waves generated by the impact arrived at the New Jersey continental slope 1-2 min after the event. Large grains $(2 \mathrm{~cm}$ to 1.5 $\mathrm{mm}$ ) and a few scattered tektite fragments were the first to settle on the seabed, arriving to the seafloor from 20 to $60 \mathrm{~min}$ after the impact. These clasts were later disturbed by tsunami waves which began to arrive at Site 904 at $\sim 1.86 \mathrm{hr}$ after the event. The waves led to the failure of the seabed and to the deposition of the breccia in which the large clasts and rare tektite fragments are contained (415.92-415.80 mbsf). The coarse-grained particles $(2 \mathrm{~cm}$ to $500 \mu \mathrm{m})$ settled on the seafloor $\sim 2-4 \mathrm{hr}$ after the impact, forming the bottom and middle laminae. Finer-grained particles $(250-500 \mu \mathrm{m})$ settled between 4 and $9 \mathrm{hr}$ after the impact forming the dominantly finer-grained upper lamina. The fine-grained tektites $(32-250 \mu \mathrm{m})$ settled on the seabed from $9 \mathrm{hr}$ to 14 days after the event accumulating an 11-cm-thick section of dark-colored silty clay. Low-energy submarine currents or tsunamis that traveled the breadth of the Atlantic Basin contributed to the deposition of laminated sediment and small-scale slumping as the seafloor and water column stabilized.

At Site 904, middle Eocene foraminifers occur within the upper Eocene tektite horizon and for $21.5 \mathrm{~m}$ above the tektite layer (Snyder et al., this volume; Fig. 14). Allogenic specimens of planktonic foraminifers and nannofossils were found at Site 612 within the tektitebearing sediment and up to $39.4 \mathrm{~m}$ above the tektite layer (Poag and Low, 1987; Miller et al., 1991; Poag and Aubry, 1995). The tektitebearing sediment at Site 612 was deposited above an erosional surface and major unconformity between Zones NP16-NP19/20 (Glass, 1989; Poag and Aubry, 1995). This large unconformity was not noted at the level of the tektites at Site 904 where an unconformity between the middle and upper Eocene (Zones NP16-NP18) occurs $8 \mathrm{~m}$ below the tektite horizon (Fig. 14).

At Site 612, Miller et al. (1991) showed that middle Eocene foraminifers contained within the tektite horizon resulted from massive reworking due to bioturbation from middle Eocene sediment beneath the tektites. Miller et al. (1991) attributed the minor reworking of middle Eocene planktonic foraminifers, that occurs for over $10 \mathrm{~m}$ above the tektite horizon, to erosion of local slope outcrops. Poag and Aubry (1995) proposed that the allogenic specimens above the tektite horizon at Site 612 were related to Toms Canyon "impact crater." According to Poag and Aubry (1995) the Site 612 tektites were emplaced by a subaqueous debris "injection" as a result of an explosive displacement of sediment derived from the Toms Canyon impact, and the "impact crater" provided the source for the allogenic specimens. Poag and Aubry (1995) indicated that although there is a sharp scoured surface beneath the tektite horizon suggestive of erosion by 
a "debriite," there is also a significant biostratigraphic gap. This unconformity correlates with unconformities on other margins and could be related to eustatic lowering (Miller et al., 1990).

An alternative explanation for the observed depositional relationships is that impact-generated failures led to the erosion of the slope. We recognize that the unconformity at Site 612 could have occurred prior to the impact, but suggest that further erosion as a result of impact-related tsunamis contributed to the exposure of middle Eocene sediment. These local exposures of middle Eocene sediment were the source or sources for the middle Eocene foraminifers contained above the Site 904 and 612 tektite-bearing sediment. This interpretation is supported by the following:

1. Mass wasting occurred beneath the tektite laminae at Site 904 , which suggests that slope failures could have also occurred at other slope locations.

2. The scale of reworking of middle Eocene foraminifers increased dramatically just above the tektite layer (Snyder et al., this volume). This cannot be attributed to bioturbation or related to a eustatic lowering because the unconformity between the upper and middle Eocene at Site 904 is $8 \mathrm{~m}$ below the tektite-horizon and middle Eocene foraminifers are rare throughout the 8-m upper Eocene section.

3. Shocked quartz and tektite fragments are contained in the breccia deposit beneath the tektite laminae showing an association between slope failures and the impact event.

4. The laminations and soft-sediment deformation features contained in the tektite-bearing sediment indicate that tektite deposition was accompanied by currents and sediment failure.

5. The irregular scoured surface above the unconformity at Site 612 suggests that erosion occurred. The absence of coarse-grained tektites at Site 903 suggests that the tektite-bearing horizon was eroded. However, it is also possible that the ejecta at Site 904, 903, and 612 are sufficiently far away from the "impact crater" ( $>2.5$ crater diameters) to form part of the discontinuous ejecta (Koeberl, 1989. 1994) and that tektites were not deposited at Site 903.

The depositional sequence of events proposed for the emplacement of the impact ejecta explains several facts: (1) localized slope failures and the absence of shallow-water assemblages, (2) exposure of middle Eocene strata as a source for the middle Eocene planktonic foraminifers mixed in the upper Eocene sediment above the tektite horizon, and (3) the possibility that the tektites were deposited by gravity settling and later displaced as mass flows.

\section{CONCLUSIONS}

A late Eocene impact event lead to the deposition of a tektite layer on the New Jersey continental slope. The tektites recovered from Site 904 are concentrated in three laminae that are contained in upper Eocene biosiliceous chalks. Biostratigraphic and major oxide analyses of the tektites and enclosing sediment indicate that the Site 904 tektites are correlative to those of Site 612. Quartz and feldspar grains that show evidence of shock metamorphism are associated with the Site 904 tektites indicating that they also form part of the ejecta. The ejecta has a fining-upward grain-size distribution consistent with gravity settling. Benthic foraminifer assemblages contained in the tektite-bearing sediment are bathyal ruling out a shallow-water turbidity-current origin for the deposition of the layers. Settling of the ejecta through the air and water column is the mechanism proposed for the deposition of the tektites. The ejecta settled on an unstable seafloor where small-scale failures led to the deposition of clay in between the tektites. It is also possible that there were pulses of deposition within an overall fining-upward sequence.

Major oxide analyses of the tektites indicate a narrow range in composition suggestive of a single source for their origin. The depo- sitional relationships of Site 904 tektite-bearing sediment and major oxide analyses of Site 904 tektites suggests that Site 904 and Site 612 tektites originated from a single impact event that excavated a heterogeneous source. Biostratigraphic and major oxide analyses correlate Site 904 tektites to Site 612 and to the North American strewn field. The Chesapeake Bay "crater" that was excavated into diverse rocks of the Appalachian orogen is a possible source for the Site 904 and 612 tektites and the North American strewn field.

The laminated character of the sediment and deformation features contained in the tektite-bearing horizon suggest that deposition of the tektites on the New Jersey continental slope was accompanied by mass-wasting and gravity-flow processes. These events are interpreted to have been generated as a result of disturbances to the seafloor and water column by tsunami waves and possibly shock waves.

\section{ACKNOWLEDGMENTS}

We are grateful to K.G. Miller, G.S. Mountain, P. Blum, and the Leg 150 Shipboard Scientific Party for providing the opportunity to study the Site 904 tektites. We thank the captain, officers, and the crew of the JOIDES Resolution for their efforts during the collection of the data. C. McHugh is especially thankful to William B.F. Ryan, Billy Glass, John Longhi and Klaus Jacobs for their contributions to this study. We are thankful to Carlos Pirmez for discussions and the calculations of settling velocities, Dee Breger from Lamont-Doherty Earth Observatory for her support in the SEM/EDX and geochemical analyses, Lenny Canone from Queens College (QC) for the preparation of the petrographic thin sections, and Tomas Liogys (QC) for his support in the analyses of the tektites. Reviewers David Powars and Wylie Poag contributed to the manuscript with their suggestions. This study was supported by JOI/USSAC. This is Lamont-Doherty Earth Observatory contribution number 5450.

\section{REFERENCES}

Barnes, V.E., 1973. Tektites. In Barnes, V.E., and Alvarez, L.W. (Eds.), Tektites: Stroudsburg, PA (Dowden Hutchinson, and Ross), 127-138.

Berggren, W.A., and Miller, K.G., 1988. Paleogene tropical planktonic foraminiferal biostratigraphy and magnetobiochronology. Micropaleontology, 34:362-380.

Bohor, B.F., Betterson, W.J., and Foord, E.E., 1988. Coesite, glass, and shocked quartz and feldspar at DSDP Site 612: evidence for nearby impact in the late Eocene. Lunar Planet. Sci., 19:114-115. (Abstract)

Brown, G., and Brindley, G.W., 1980. X-ray diffraction procedures for clay mineral identification. In Brindley, G.W., and Brown, G. (Eds.), Crystal Structures of Clay Minerals and Their X-ray Identification. Mineral. Soc. Monogr. London, 5:305-359.

Chamley, H., 1989. Clay Sedimentology: Berlin (Springer-Verlag).

Deconinck, J.F., and Chamley, H., in press. Diversity of smectite origins in Late Cretaceous sediments: example of chalks from Northern France. Clay Miner.

D'Hondt, S.L., Keller, G., and Stallerd, R.F., 1987. Major element compositional variations within and between different late Eocene microtektite strewn fields. Meteoritics, 22:61-79.

Dobrin, M.B., and Savit, C.H., 1988. Introduction to Geophysical Prospecting (4th ed.): New York (McGraw-Hill).

Evans, J.N., Shahinpoor, M., and Ahrens, T.J., 1994. Hypervelocity impact: ejecta velocity, angle, and composition. In Dressler, B.O., Grieve, R.A.F., and Sharpton, V.L. (Eds.), Large Meteorite Impacts and Planetary Evolution. Spec. Pap.-Geol. Soc. Am., 293:93-101.

Faul, H., 1966. Tektites are terrestrial. Nature, 152:1341-1344.

Gibbs, R.J., Matthews, M.D., and Link, D.A., 1971. The relationship between sphere size and settling velocity. J. Sediment. Petrol., 41:7-18.

Glass, B.P., 1982. Possible correlation between tektite events and climatic changes? Spec. Pap.-Geol. Soc. Am., 190:251-258.

, 1984. Solution of naturally-occurring glasses in the geological environment, J. Non-Cryst. Solids, 67:265-286.

, 1989. North American tektite debris and impact ejecta from DSDP Site 612. Meteoritics, 24:209-218. 
1990. Tektites and microtektites: key facts and inferences. Tectonophysics, 171:393-404.

Glass, B.P., and Burns, C.A., 1987. Late Eocene crystal-bearing spherules: two layers or one? Meteoritics, 22:265-279.

Glass, B.P., Burns, C.A., Crosbie, J.R., and DuBois, D.L., 1985. Late Eocene North American microtektites and clinopyroxene-bearing spherules. Proc. 15th Lunar Planet. Sci. Conf., 1:175-195.

Glass, B.P., and Koeberl, C., 1989. Trace element study of high- and lowrefractive index Muong Nong-type tektites from Indochina. Meteoritics, 24:143-146.

Glass, B.P., Muenow, D.W., and Aggrey, K.E., 1986. Further evidence for the impact origin of tektites. Meteoritics, 21:369-370.

Glass, B.P., Swincki, M.B., and Zwart, P.A., 1979. Australasian, Ivory Coast and North American tektite strewn fields: size, mass and correlation with geomagnetic reversals and other earth events. Proc. 10th Lunar Planet. Sci. Conf., 2535-2545.

Glass, B.P., and Zwart, M.J., 1979. North American microtektites in Deep Sea Drilling Project cores from the Caribbean Sea and Gulf of Mexico. Geol. Soc. Am. Bull., 90:595-602.

Hazel, J.E., 1989. Chronostratigraphy of upper Eocene microspherules. Palaios, 4:318-329.

Holtzapffel, T., 1985. Les minéraux argileux: préparation, analyse diffractométrique et détermination. Publ. Soc. Geol. Nord., 12.

Kastner, M., Asaro, F., Michel, H.V., Alvarez, W., and Alvarez, L.W., 1984. The precursor of the Cretaceous-Tertiary boundary clays at Stevns Klint, Denmark, and DSDP Hole 465A. Science, 226:137-143.

Keller, G., D'Hondt, S.L., Orth, C.J., Gilmore, J.S., Oliver, P.Q., Shoemaker, E.M., and Molina, E., 1987. Late Eocene impact microspherules: stratigraphy, age and geochemistry. Meteoritics, 22:25-59.

King, E.A., 1962. Field investigation of Georgia tektites and description of new specimens. Georgia Min. Newsl., 15:84-89.

, 1977. The origin of tektites: a brief review. Am. Sci., 65:212-218.

Koeberl, C., 1986. Geochemistry of tektites and impact glasses. Annu. Rev. Earth Planet. Sci., 14:323-50.

, 1989. New estimates of area and mass for the North American tektite strewn field. Proc. 19th Lunar Planet. Sci. Conf., 745-751.

, 1994. Tektite origin by hypervelocity asteroidal or cometary impact: target rocks, source craters, and mechanisms. In Dressler, B.O., Grieve, R.A.F., and Sharpton, V.L. (Eds.), Large Meteorite Impacts and Planetary Evolution. Spec. Pap.-Geol. Soc. Am., 293:133-151.

Koeberl, C., and Glass, B.P., 1988. Chemical composition of North American microtektites and tektite fragments from Barbados and DSDP Site 612 on the continental slope off New Jersey. Earth Planet. Sci. Lett., 87:286-292.

Lever, A., and McCave, I.N., 1983. Eolian components in Cretaceous and Tertiary North Atlantic sediments. J. Sediment. Petrol., 53:811-832.

Miller, K.G., Berggren, W.A., Zhang, J., and Palmer-Julson, A.A., 1991. Biostratigraphy and isotope stratigraphy of upper Eocene microtektites at Site 612: how many impacts? Palaios, 6:17-38.

Miller, K.G., and Katz, M.E., 1987. Eocene benthic foraminiferal biofacies of the New Jersey Transect. In Poag, C.W., Watts, A.B., et al., Init. Repts. DSDP, 95: Washington (U.S. Govt. Printing Office), 253-265.

Miller, K.G., Kent, D.V., Brower, A.N., Bybell, L.M., Feigenson, M.D., Olsson, R.K., and Poore, R.Z., 1990. Eocene-Oligocene sea-level changes on the New Jersey coastal plain linked to the deep-sea record. Geol. Soc. Am. Bull., 102:331-339.

Moore, D.M., and Reynolds, R.C., Jr., 1989. X-ray Diffraction and the Identification and Analysis of Clay Minerals: Oxford (Oxford Univ. Press).

O'Keefe, J.D., and Ahrens, T.J., 1982. The interaction of the Cretaceous/Tertiary extinction bolide with the atmosphere, ocean, and solid Earth. In Silver, L.T., and Schultz, P.H. (Eds.), Geologic Implications of Impacts of Large Asteroids and Comets on the Earth. Spec. Pap.-Geol. Soc. Am., 190:103-120.
Poag, C.W., and Aubry, M.-P., 1995. Upper Eocene impactites of the U.S. coast: depositional origins, biostratigraphic framework, and correlation. Palaios, 10:16-43.

Poag, C.W., and Low, D., 1987. Unconformable sequence boundaries at Deep Sea Drilling Project Site 612, New Jersey Transect: their characteristics and stratigraphic significance. In Poag, C.W., Watts, A.B., et al., Init. Repts. DSDP, 95: Washington (U.S. Govt. Printing Office), 453500 .

Poag, C.W., and Mountain, G.S., 1987. Late Cretaceous and Cenozoic evolution of the New Jersey continental slope and upper rise: an integration of borehole data with seismic reflection profiles. In Poag, C.W., Watts, A.B., et al., Init. Repts. DSDP, 95: Washington (U.S. Govt. Printing Office), 673-724.

Poag, C.W., Poppe, L.J., Folger, D.W., Powars, D.S., Mixon, R.B., Edwards, L.E., and Bruce, S., 1993. Deep Sea Drilling Project Site 612 bolide event: new evidence of a late Eocene impact-wave deposit and a possible impact site, U.S. east coast: reply. Geology, 21:478-479.

Poag, C.W., Powars, D.S., Mixon, R.B., and Bruce, S., 1994a. Convulsive events in Atlantic Coastal Plain evolution: effects of the Chesapeake Bay bolide impact. Geol. Soc. Am., Abstr. Progr., 26:152.

Poag, C.W., Powars, D.S., Poppe, L.J., and Mixon, R.B., 1994b. Meteoroid mayhem in Ole Virginny: source of the North American tektite strewn field. Geology, 22:691-694.

Poag, C.W., Powars, D.S., Poppe, L.J., Mixon, R.B., Edwards, L.E., Folger, D.W., and Bruce, S., 1992. Deep Sea Drilling Project Site 612 bolide event: new evidence of a late Eocene impact-wave deposit and a possible impact site, U.S. east coast. Geology, 20:771-774.

Poag, C.W., and Sevon, W.D., 1989. A record of Appalachian denudation in postrift Mesozoic and Cenozoic sedimentary deposits of the U.S. middle Atlantic continental margin. Geomorphology, 2:119-157.

Poag, C.W., Watts, A.B., et al., 1987. Init. Repts. DSDP, 95: Washington (U.S. Govt. Printing Office).

Robertson, P.B., Dence, M.R., and Vos, M.A., 1968. Deformation in rockforming minerals from Canadian craters. In French, B.M., and Short, N.M. (Eds.), Shock Metamorphism of Natural Materials: Baltimore (Mono Book Corp.), 433-452.

Shipboard Scientific Party, 1994. Site 904. In Mountain, G.S., Miller, K.G., Blum, P., et al., Proc. ODP, Init. Repts., 150: College Station, TX (Ocean Drilling Program), 207-253.

Sigurdsson, H., Bonte, P., Turpin, L., Chaussidon, M., Metrich, N., Steinberg, M., Pradel, P., and D'Hondt, S., 1991. Geochemical constraints on source region of Cretaceous/Tertiary impact glasses. Nature, 353:839842.

Stecher, O., Ngo, H.H., Papanastassiou, D.A., and Wasserburg, G.J., 1989. $\mathrm{Nd}$ and $\mathrm{Sr}$ isotopic evidence for the origin of tektite material from DSDP site 612 of the New Jersey coast. Meteoritics, 24:89-98.

Thein, J., 1987. A tektite layer in upper Eocene sediments of the New Jersey continental slope (Site 612, Leg 95). In Poag, C.W., Watts, A.B., et al., Init. Repts. DSDP, 95: Washington (U.S. Govt. Printing Office), 565579.

Watts, A.B., and Steckler, M.S., 1979. Subsidence and eustasy at the continental margin of eastern North America. In Talwani, M., Hay, W., and Ryan, W.B.F. (Eds.), Deep Drilling Results in the Atlantic Ocean: Continental Margins and Paleoenvironment. Am Geophys. Union, Maurice Ewing Ser., 3:218-234.

Wei, W., 1993. Deep Sea Drilling Project Site 612 bolide event: new evidence of a late Eocene impact-wave deposit and a possible impact site, U.S. east coast: comment and reply. Geology, 5:478.

Date of initial receipt: 2 March 1995

Date of acceptance: 10 November 1995

Ms 150SR-019 

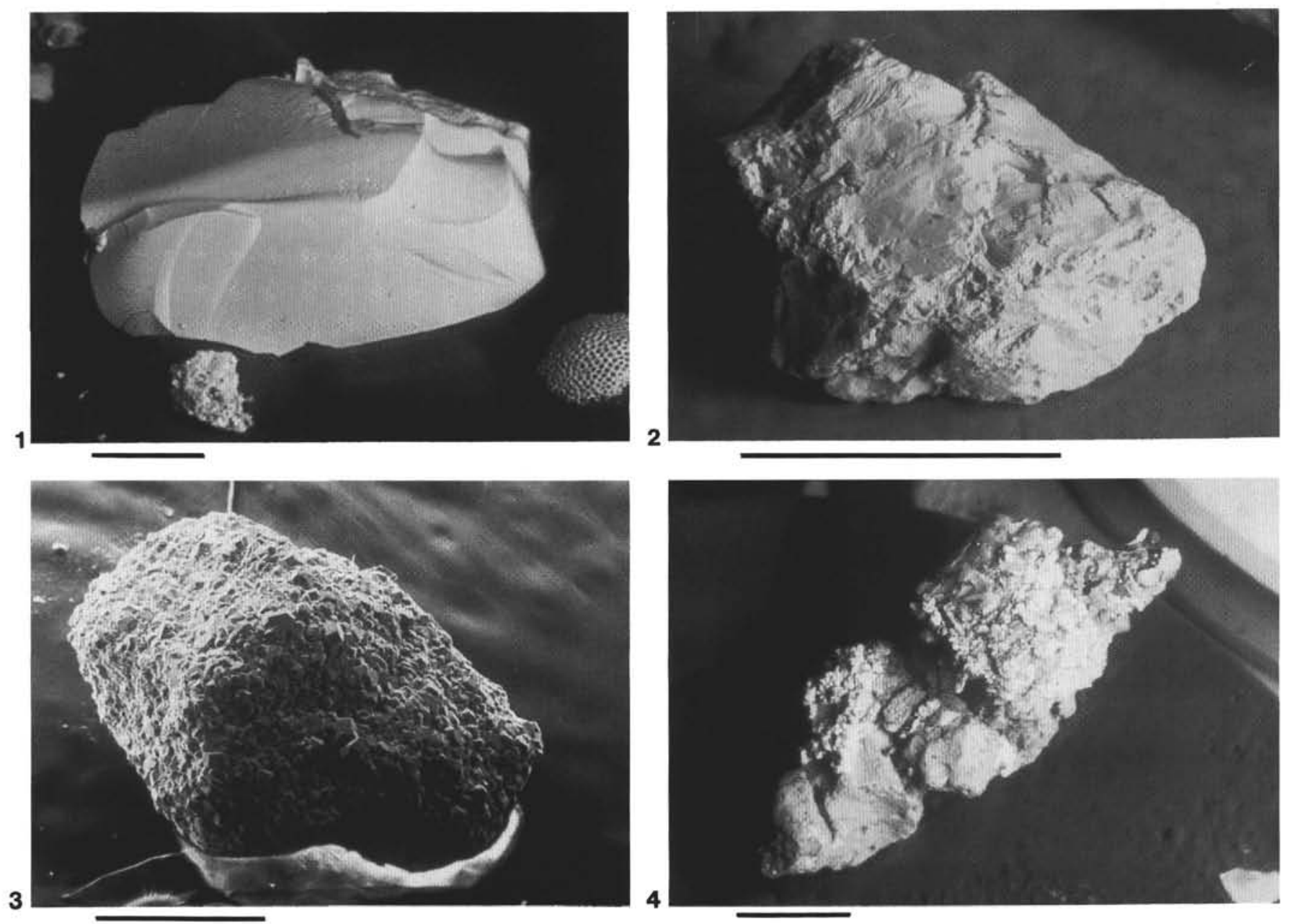

Plate 1. Site 904 tektite fragments have diverse shapes and textures. 1 . Tektite fragment with smooth surface, Sample $150-904 \mathrm{~A}-45 \mathrm{X}-2,92-93 \mathrm{~cm} . \mathrm{Scale}$ bar $=$ $100 \mu \mathrm{m}$. 2. Large tektite fragment with rough surface, Sample 150-904A-45X-2, 88-89. Scale bar $=1 \mathrm{~mm}$. 3. Tektite fragment coated with pyrite crystals, Sample $150-904 \mathrm{~A}-45 \mathrm{X}-2,88-89 \mathrm{~cm}$. Scale bar $=400 \mu \mathrm{m}$. 4. Tektite fragments cemented together and covered with pyrite, Sample 150-904A-45X-2, 87-88 cm. Scale bar $=1 \mathrm{~mm}$. 

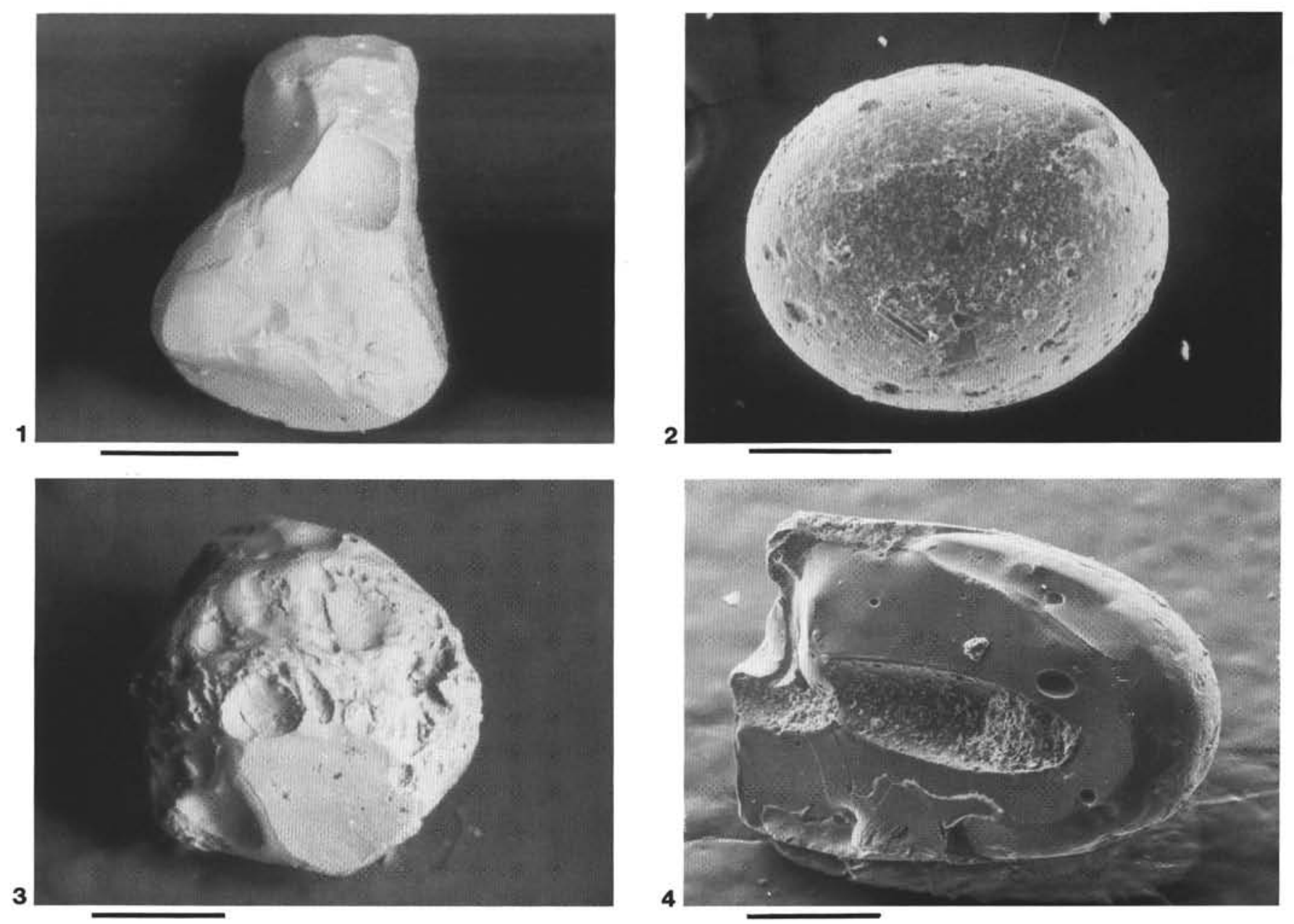

Plate 2. Splash form Site 904 microtektites. 1. Dumbbell-shaped microtektite with large vesicle, Sample $150-904 \mathrm{~A}-45 \mathrm{X}-2,79-80 \mathrm{~cm}$. Scale bar $=200 \mu \mathrm{m} .2$. Spherical large microtektite $(>1 \mathrm{~mm})$ with vesicles and a coating of pyrite, Sample 150-904A-45X-2, 86-87 cm. Scale bar $=400 \mu \mathrm{m}$. 3. Spherical large microtektite with abundant vesicles and a pitted surface, Sample 150-904A-45X-2, 88-89. Scale bar $=400 \mu \mathrm{m}$. 4. Porous, oval large microtektite, Sample 150$904 \mathrm{~A}-45 \mathrm{X}-2,88-89 \mathrm{~cm}$. Scale bar $=400 \mu \mathrm{m}$. 

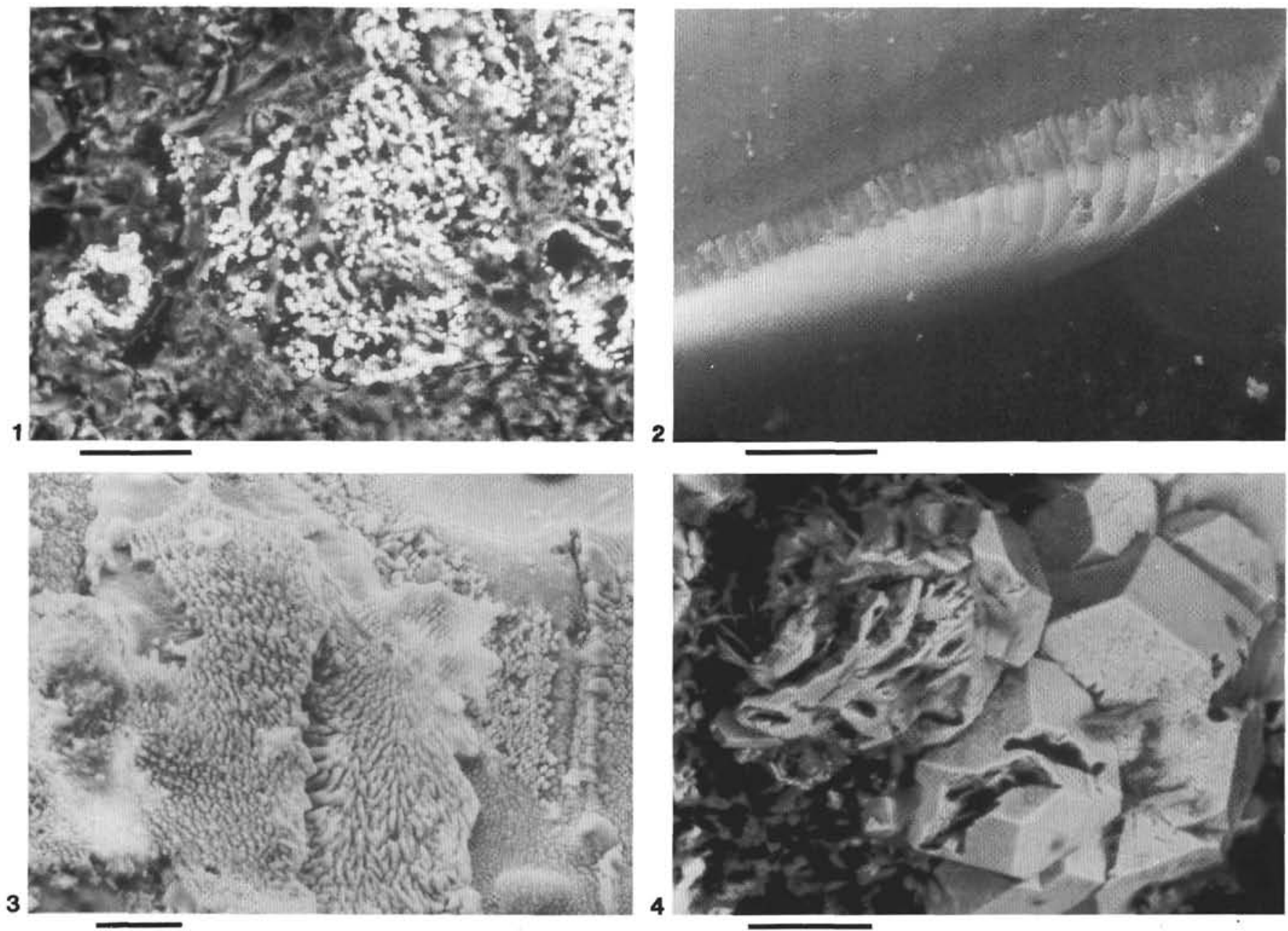

Plate 3. Surface textures of Site 904 tektite fragments and microtektites. 1. Backscatter micrograph showing microtektite with copper on its surface, Sample $150-904 \mathrm{~A}-45 \mathrm{X}-2,79-80 \mathrm{~cm}$. Scale bar $=200 \mu \mathrm{m}$. 2. Tektite fragment showing striated surface, Sample $150-904 \mathrm{~A}-45 \mathrm{X}-2,92-93 \mathrm{~cm}$. Scale bar $=20 \mu \mathrm{m} .3$. Irregular glass texture on microtektite surface, Sample $150-904 \mathrm{~A}-45 \mathrm{X}-2,87-88 \mathrm{~cm}$. Scale bar $=20 \mu \mathrm{m}$. 4. Pyrite crystals on tektite surface, Sample $150-904 \mathrm{~A}-$ $45 \mathrm{X}-2,85-86 \mathrm{~cm}$. Scale bar $=20 \mu \mathrm{m}$. 

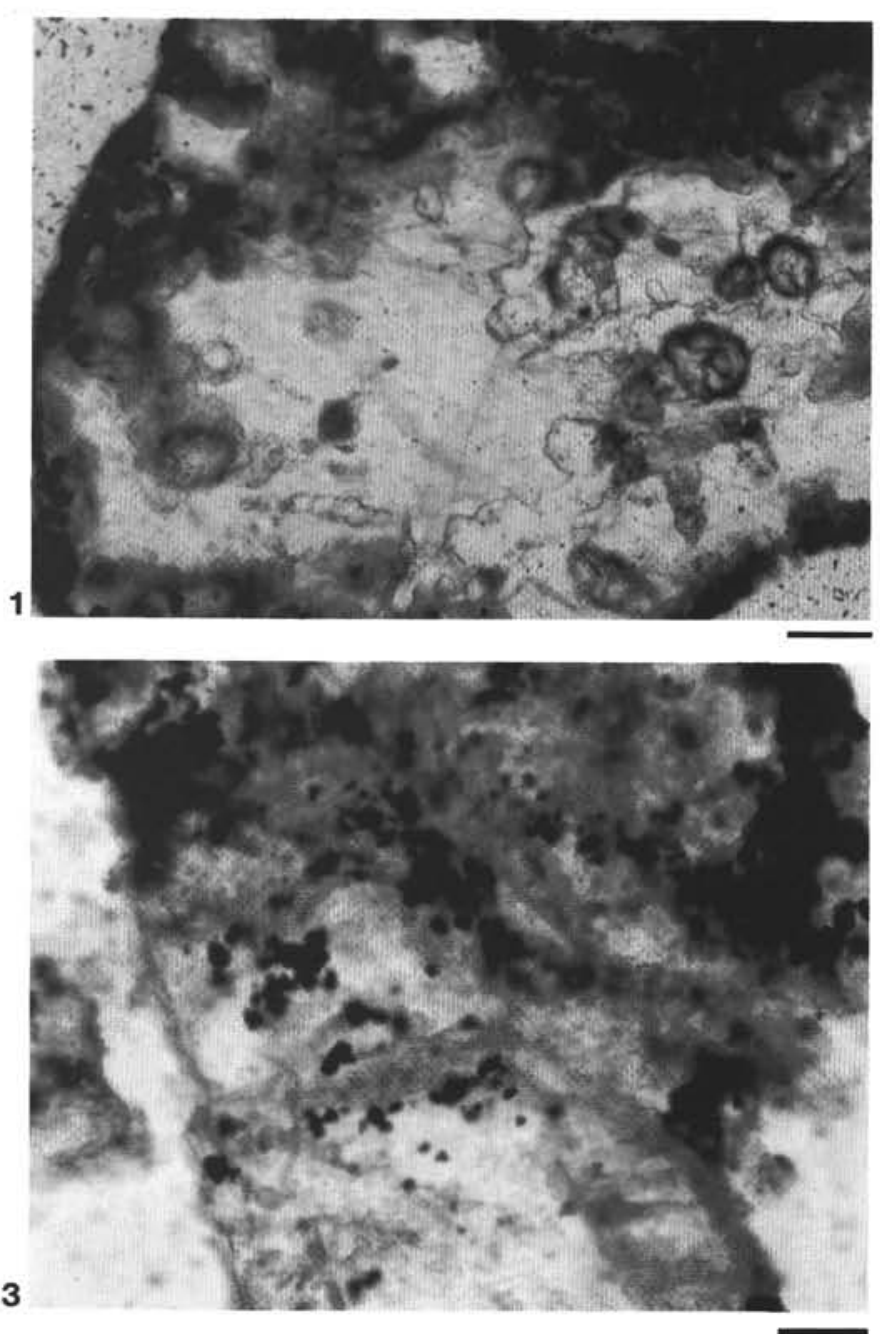
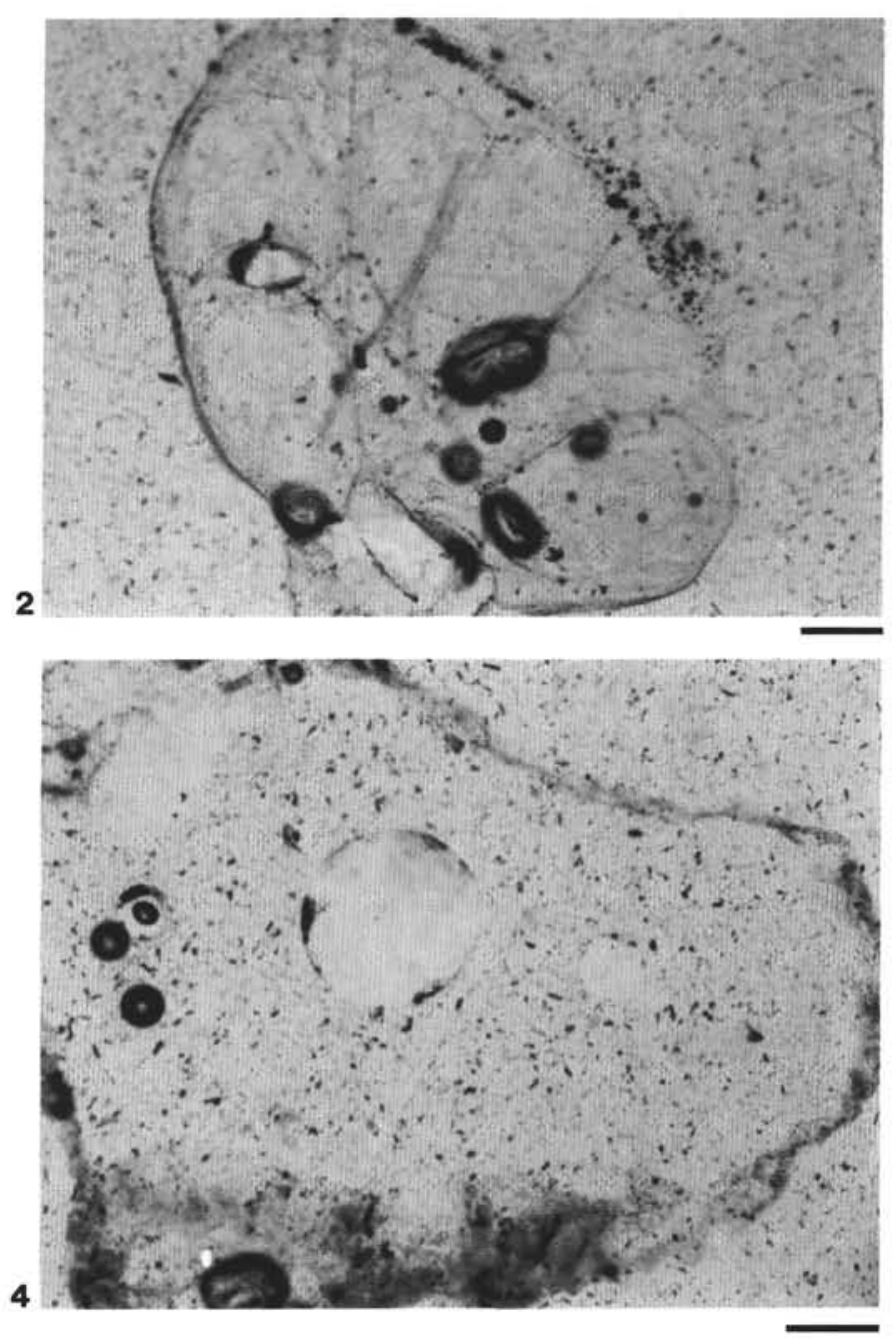

Plate 4. Thin sections of Site 904 tektites with vesicles and sulfide coatings. 1. Tektite with sulfide rim and abundant vesicles, Sample 150-904A-45X-2, 86-87 $\mathrm{cm}$. Scale bar $=100 \mu \mathrm{m}$. 2. Tektite with vesicles and inclusions, Sample $150-904 \mathrm{~A}-45 \mathrm{X}-2,88-89 \mathrm{~cm}$. Scale bar $=100 \mu \mathrm{m}$. 3. Irregular tektite with sulfide coating, Sample $150-904 \mathrm{~A}-45 \mathrm{X}-2,86-87 \mathrm{~cm}$. Scale bar $=50 \mu \mathrm{m}$. 4. Tektite with a large vesicle, Sample $150-904 \mathrm{~A}-45 \mathrm{X}-2,88-89 \mathrm{~cm}$. Scale bar $=100 \mu \mathrm{m}$. 

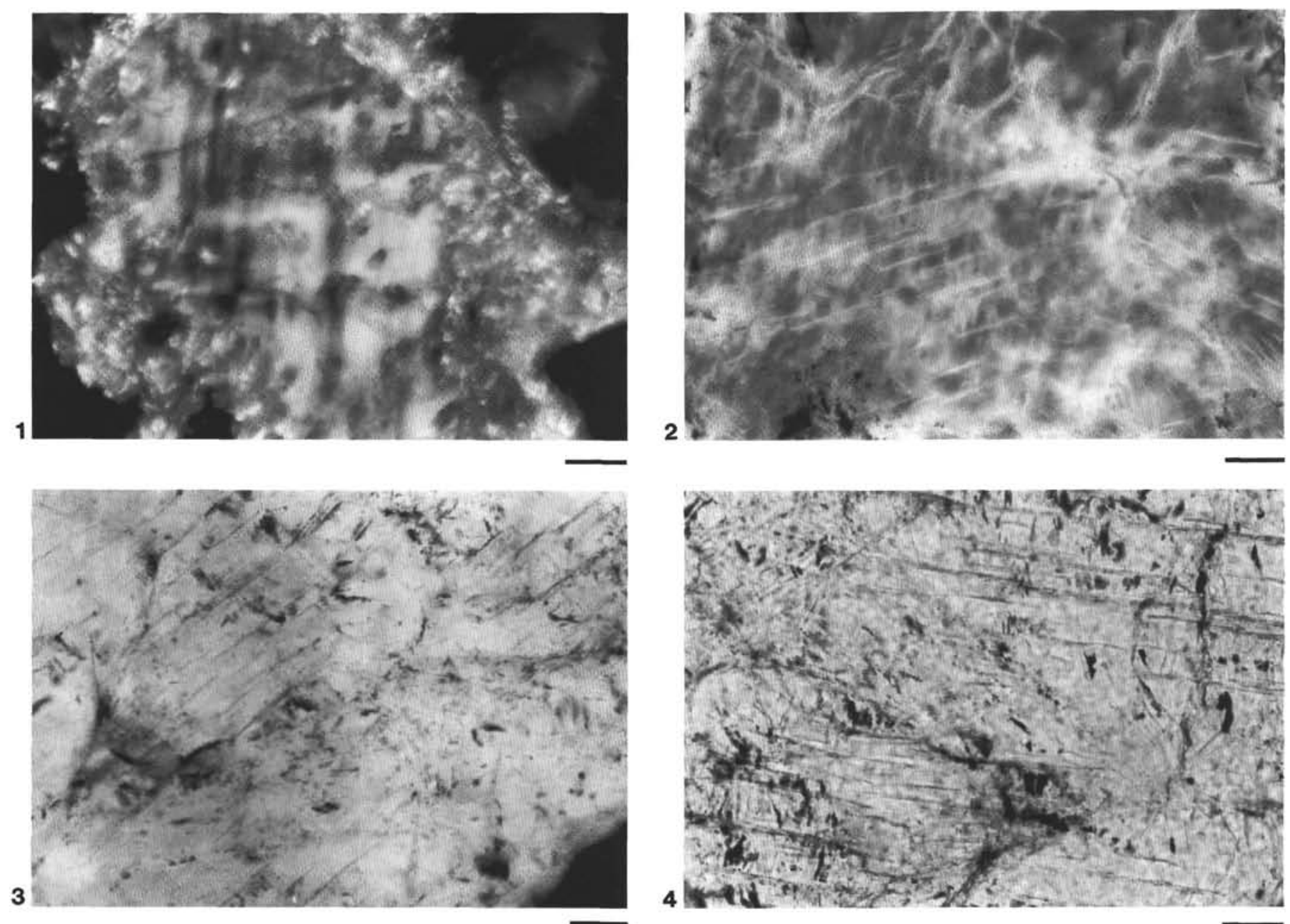

Plate 5. Thin sections of Site 904 impact ejecta. 1. Feldspar grain with at least four sets of lamellae, Sample $150-904 \mathrm{~A}-45 \mathrm{X}-2,91-92 \mathrm{~cm}$. Scale bar $=50 \mu \mathrm{m} .2$. Undulatory, fractured feldspar grain, Sample $150-904 \mathrm{~A}-45 \mathrm{X}-2,86-87 \mathrm{~cm}$. Scale bar $=25 \mu \mathrm{m}$. 3. Quartz grain with at least four sets of lamellae, Sample $150-$ 904A-45X-2, 91-92 cm. Scale bar $=250 \mu \mathrm{m}$. 4. Shocked quartz grain with planar features, Sample 150-904A-45X-2, 91-92 cm. Scale bar $=50 \mu \mathrm{m}$. 